\title{
An Evaluation of the Tax-Transfer Treatment of Married Couples in European Countries
}

Immervoll, Herwig; Kleven, Henrik Jacobsen; Kreiner, Claus Thustrup; Verdelin, Nicolaj

Publication date:

2009

Document version

Publisher's PDF, also known as Version of record

Citation for published version (APA):

Immervoll, H., Kleven, H. J., Kreiner, C. T., \& Verdelin, N. (2009). An Evaluation of the Tax-Transfer Treatment of Married Couples in European Countries. 


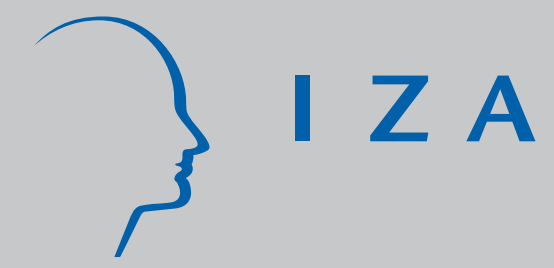

IZA DP No. 3965

An Evaluation of the Tax-Transfer Treatment of Married Couples in European Countries

Herwig Immervoll

Henrik J acobsen Kleven

Claus Thustrup Kreiner

Nicolaj Verdelin

J anuary 2009 


\title{
An Evaluation of the Tax-Transfer Treatment of Married Couples in European Countries
}

\author{
Herwig Immervoll \\ OECD, ISER, University of Essex and IZA \\ Henrik Jacobsen Kleven \\ London School of Economics and CEPR \\ Claus Thustrup Kreiner \\ University of Copenhagen and CESifo
}

Nicolaj Verdelin

University of Copenhagen

Discussion Paper No. 3965
January 2009

IZA

P.O. Box 7240

53072 Bonn

Germany

Phone: +49-228-3894-0

Fax: +49-228-3894-180

E-mail: iza@iza.org

\begin{abstract}
Any opinions expressed here are those of the author(s) and not those of IZA. Research published in this series may include views on policy, but the institute itself takes no institutional policy positions.

The Institute for the Study of Labor (IZA) in Bonn is a local and virtual international research center and a place of communication between science, politics and business. IZA is an independent nonprofit organization supported by Deutsche Post Foundation. The center is associated with the University of Bonn and offers a stimulating research environment through its international network, workshops and conferences, data service, project support, research visits and doctoral program. IZA engages in (i) original and internationally competitive research in all fields of labor economics, (ii) development of policy concepts, and (iii) dissemination of research results and concepts to the interested public.
\end{abstract}

IZA Discussion Papers often represent preliminary work and are circulated to encourage discussion. Citation of such a paper should account for its provisional character. A revised version may be available directly from the author. 


\section{ABSTRACT}

\section{An Evaluation of the Tax-Transfer Treatment of Married Couples in European Countries}

This paper presents an evaluation of the tax-transfer treatment of married couples in $15 \mathrm{EU}$ countries using the EUROMOD microsimulation model. First, we show that many tax-transfer schemes in Europe feature negative jointness defined as a situation where the tax rate on one person depends negatively on the earnings of the spouse. This stands in contrast to the previous literature on this question, which has focused on a specific form of positive jointness. The presence of negative jointness is driven by family-based and means-tested transfer programs combined with tax systems that usually feature very little jointness. Second, we consider the labour supply distortion on secondary earners relative to primary earners implied by the current tax-transfer systems, and study the welfare effects of small reforms that change the relative taxation of spouses. By adopting a small-reform methodology, it is possible to set out a simple analysis based on more realistic labour supply models than those considered in the existing literature. We present microsimulations showing that simple revenue-neutral reforms that lower the tax burden on secondary earners are associated with substantial welfare gains in most countries. Finally, we consider the taxtransfer implications of marriage and estimate the so-called marriage penalty. For most countries, we find large marriage penalties at the bottom of the distribution driven primarily by features of the transfer system.

JEL Classification: $\quad \mathrm{H} 20$

Keywords: labour supply, redistribution, optimal tax, couples, marriage tax, joint taxation

Corresponding author:

Henrik Kleven

Department of Economics and STICERD

London School of Economics and Political Science

Houghton Street

London WC2A 2AE

United Kingdom

E-mail: h.j.kleven@Ise.ac.uk

\footnotetext{
* We thank Emmanuel Saez and seminar participants at the CESifo 2008 area conference on public sector economics for comments. The project has been supported by a grant from the Economic Policy Research Network (EPRN). Any remaining errors and views expressed in this article are the authors' responsibility. In particular, the paper does not necessarily represent the views of the OECD, the governments of OECD member countries or the EUROMOD consortium. The version of EUROMOD used in this paper relies on micro-data from 11 different sources for 15 countries. These are the European Community Household Panel (ECHP) made available by Eurostat; the Austrian version of the ECHP made available by the Interdisciplinary Centre for Comparative Research in the Social Sciences; the Living in Ireland Survey made available by the Economic and Social Research Institute; the Panel Survey on Belgian Households (PSBH) made available by the University of Liège and the University of Antwerp; the Income Distribution Survey made available by Statistics Finland; the Enquête sur les Budgets Familiaux (EBF) made available by INSEE; the public use version of the German Socio Economic Panel Study (GSOEP) made available by the German Institute for Economic Research (DIW), Berlin; the Survey of Household Income and Wealth (SHIW95) made available by the Bank of Italy; the Socio-Economic Panel for Luxembourg (PSELL-2) made available by CEPS/INSTEAD; the Socio-Economic Panel Survey (SEP) made available by Statistics Netherlands through the mediation of the Netherlands Organisation for Scientific Research - Scientific Statistical Agency; the Income Distribution Survey made available by Statistics Sweden; and the Family Expenditure Survey (FES), made available by the UK Office for National Statistics (ONS) through the Data Archive. Material from the FES is Crown Copyright and is used by permission. Neither the ONS nor the Data Archive bear any responsibility for the analysis or interpretation of the data reported here.
} 
TABLE OF CONTENTS

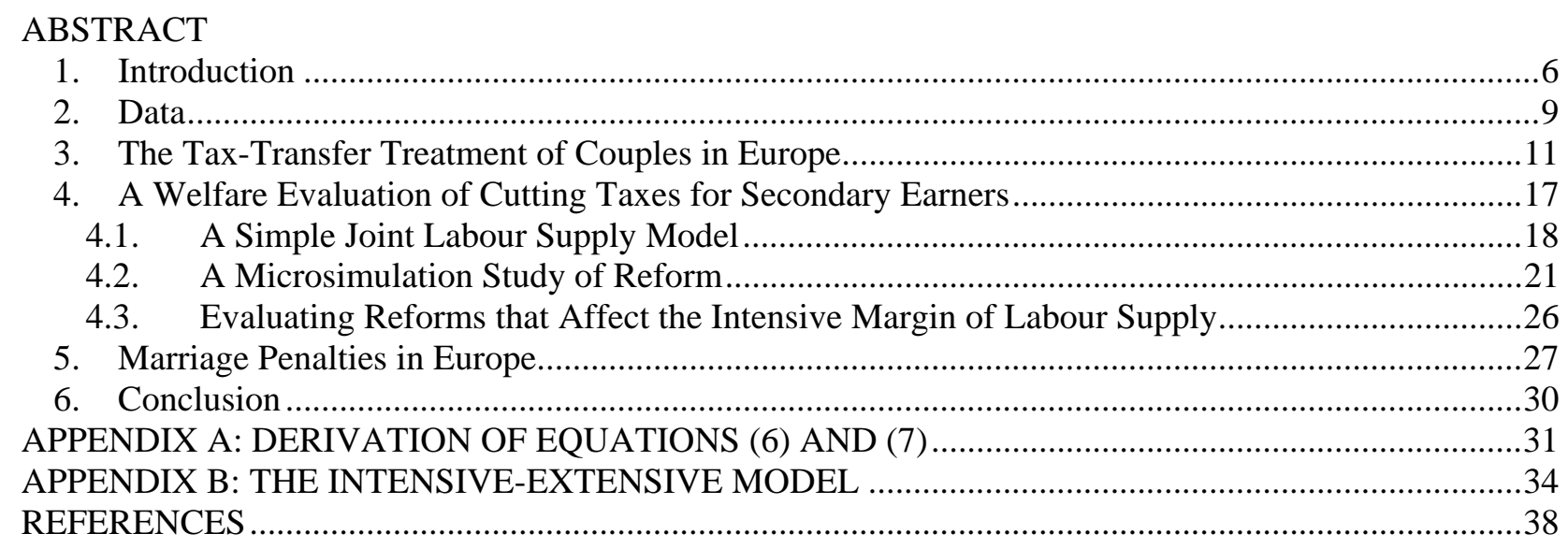

\section{Tables}

Table 1. Share of women among secondary earners 41

Table 2. Participation tax rates and labour market outcomes ..................................................................42

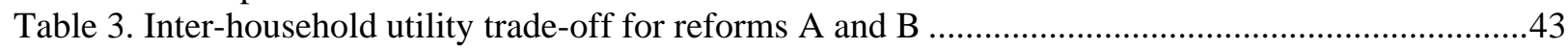

Table 4. Inter-household utility trade-off for reform C .........................................................................4

Table 5. Annual marriage penalties in 2007 euros for families with two children, 1998 .........................45

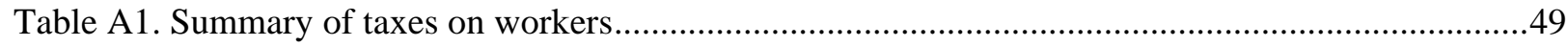

Table A2. Summary of social benefits available to persons of working-age............................................51

Table A3. Average marginal tax rates ..................................................................................................53

Table A4. Annual marriage penalties in 2007 euros for families with no children, 1998 .......................53

\section{Figures}

Figure 1. Participation tax rates of secondary earners for couples with two children ...............................46

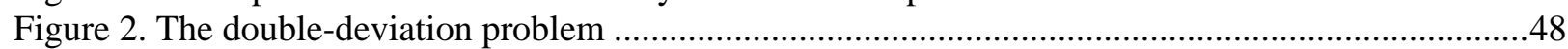

Figure A1. Marginal tax rates of secondary earners for couples with two children ................................54

Figure A2. Participation tax rates of secondary earners for couples without children ..............................56 


\section{Introduction}

The tax treatment of couples has been a debating point throughout the existence of the income tax. Actual policies have varied over time and across countries. Over the past three decades, there has been an international trend from joint to individual taxation of husbands and wives, and today the majority of OECD countries use the individual as the basic unit of taxation. Under fully individual taxation, tax liability is assessed separately for each family member and is therefore independent of the income of other individuals living in the household. By contrast, in a system of fully joint taxation of couples, as operated by for example the United States, tax liability is assessed at the family level and depends on total family income. Three basic points have been noted in previous discussions of the choice between individual and joint taxation (e.g. Rosen, 1977; Boskin and Sheshinski, 1983; Pechman, 1987).

The first argument is an efficiency argument. It starts from the empirical observation that the secondary earner in a family - typically the wife - tends to have a more elastic labour supply than the primary earner (e.g. Blundell and MaCurdy, 1999). A Ramsey-type optimal tax rule then suggests that the labour income of secondary earners should be taxed at a lower rate than the labour income of primary earners. This is achieved to a certain degree by a progressive individual income tax, because primary earners have higher incomes and therefore face higher marginal tax rates than their spouses. On the other hand, a fully joint income tax creates identical marginal tax rates across members of the same household and hence does not meet this efficiency criterion.

The second argument is that tax systems should be neutral with respect to marriage decisions. This can be viewed as an efficiency argument that tax systems should not distort the marriage market or as a horizontal equity argument that identical couples (married or cohabitating) should be treated identically for tax purposes. While individual-based taxation is neutral with respect to marriage, joint tax systems are generically non-neutral. Jointness may penalize or subsidize marriage depending on the exact design, and the size of penalties/subsidies generally depends on the distribution of income within the family.

The third argument is an equity argument, taking as its point of departure that welfare is better measured by family income than individual income. As a result, two families with the same total income should, other things being the same, pay equal taxes. By the same token, if one family receives a higher total income than another family, then the first family should face a higher tax liability than the second one. This equity criterion is satisfied by a joint income tax that depends on total family income, but not by a progressive individual tax system, because in that case tax liability depends also on the distribution of incomes within the family. 
This paper attempts to shed light on the three issues discussed above. We start by noting that these issues ultimately pertain to the redistribution scheme as a whole, not just the tax system, and we therefore present an integrated treatment of the tax and transfer system. A recurrent theme in the paper is that the transfer system is a crucial element in understanding and evaluating redistribution schemes affecting married couples. We also point out that the focus in previous discussions on the choice between individual tax treatment and joint tax treatment based on family income represents an oversimplification, because realworld redistribution schemes are almost never fully individual or fully joint. There are two reasons for this. First, while most countries have adopted individual filing in the tax system, they tend to retain certain elements of jointness such as the transfer of unused allowances across spouses, dependent spouse exemptions, etc. Second, significant parts of transfer systems are fully joint, because social benefits are means-tested according to the combined income (and often assets) of the two spouses in the household. This implies that actual redistribution systems typically combine a form of quasi-individual taxation with family-based transfer systems, creating a fairly complicated jointness structure that is different from the two polar cases typically analyzed.

This paper presents a comprehensive evaluation of the tax-transfer treatment of married couples in $15 \mathrm{EU}$ countries. The analysis has three components. First, we carefully map the nature of jointness in tax-transfer schemes in our sample of countries using the EUROMOD microsimulation model. EUROMOD is built around country-specific, but partly harmonized, micro datasets combined with a detailed tax-benefit simulator capturing the full set of institutional features of tax and transfer systems in each country. We find that many tax-transfer schemes in Europe feature negative jointness defined as a situation where the tax rate on one person depends negatively on the earnings of the spouse. Such a system is opposite to the form of jointness typically analyzed in the literature - fully joint and progressive taxation - because such schemes feature a positive interaction between tax rates and spousal earnings and therefore positive jointness. The presence of negative jointness is driven by family-based and means-tested transfers combined with individual or almost-individual taxes. To see this, consider a secondary earner, say the wife, deciding about labour market entry. If she is married to a low-income husband, the family is in the phaseout range of transfer programs, and she will face a high effective tax rate. On the other hand, if she is married to a high-income husband, the family is beyond the phase-out range of transfer programs, and she will face a low effective tax rate because the income tax is individual. Hence, the wife's tax is declining in the husband's earnings.

1. An introduction to EUROMOD and a descriptive analysis of taxes and transfers in the EU countries has been provided by Sutherland (2001), Immervoll and O'Donoghue (2003), and Immervoll (2004). 
Second, the paper considers the incentives to supply labour for secondary earners relative to primary earners implied by the existing tax-transfer systems, and studies the welfare effects of reforms that change the relative taxation of spouses. This issue is separate from the nature of jointness discussed above: jointness has to do with the relationship between tax rates and spousal earnings (a cross-derivative in the tax function), whereas labour supply incentives have to do with the relationship between tax liability and own earnings (an own-derivative in the tax function). Previous work has often discussed the two issues as if they are one and the same, but we find that the distinction is important in practice. To study the welfare effects of tax-transfer reform, the paper starts by setting out a simple theoretical model that incorporates only participation responses, and then turn to a general model that allows for both participation and hoursof-work responses for both spouses in the household. Microsimulations of different revenue-neutral reforms that reduce the tax burden on secondary earners show that, for both models and for most countries, a lowering of the tax burden on secondary earners is associated with substantial welfare gains.

This part of the paper may be seen as an extension of our previous work based on single-person households (Immervoll et al., 2007) to the case of two-person households. It is also related to the recent work by Alesina and Ichino (2007), arguing that tax schemes should be gender-specific with lower rates on females. We do not consider gender-specific taxation as such (consistent with real-world tax systems that are anonymous and hence gender-blind), but consider reforms that change the taxation of primary versus secondary earners. We define primary versus secondary, not in terms of gender, but in terms of relative earnings within the family - a concept that is correlated with gender. ${ }^{2}$ Indeed, it is shown that in almost all countries more than $80 \%$ of secondary earners are women, and in some countries more than $90 \%$ of secondary earners are women. Thus, the reforms under consideration strongly target married women with low earnings or weak labour market attachment without formally discriminating based on gender. This is important because gender-specific taxation per se would raise difficult legal or constitutional issues in many countries.

Third, the paper explores the distortions in the decision to marry by simulating the size of marriage penalties resulting from the combined effect of taxes and transfers. The presence of family-based and means-tested transfers penalizes marriage at the bottom of the distribution, implying that marriage penalties at the bottom tend to go hand in hand with negative jointness. ${ }^{3}$ Indeed, we find large marriage penalties at the bottom of the distribution (but not at the top) in most countries, which raises important

2. More specifically, the lower-earning spouse in each family is defined as the secondary earner. For oneearner couples, this obviously implies that the non-working spouse is the secondary earner.

3. However, theoretically it is entirely possible to design a negatively joint tax system that subsidizes rather than penalizes marriage. 
questions pertaining to fairness as well as to efficiency. Transfers and taxes that depend on marriage are often accused by conservatives of destroying the traditional two-parent family and leading to high rates of single motherhood. Although empirical studies of the effects on marriage and divorce from income taxes (e.g. Alm and Whittington, 1997, 1999), welfare benefits (e.g. Hoynes 1997a,b; Moffitt, 1998), or taxes and benefits combined (Dickert-Conlin, 1999; Eissa and Hoynes, 2000b) tend to find modest or no effects, the existence of marriage disincentives continues to be a controversial point of contention.

Most of the literature studying the optimal design of tax and transfer programs and the evaluation of tax and welfare reform rests on models of single-person households. However, real-world tax-transfer schemes for a large part redistribute income across families formed around couples, creating a substantial gap between theory and practice. This has triggered a recent and growing interest in generalizing the theory of optimal income redistribution to explicitly deal with couples. For example, Kleven, Kreiner, and Saez $(2007,2008)$ explore the optimal nonlinear taxation of couples as a multi-dimensional screening problem, whereby agents (couples) are characterized by a multi-dimensional parameter (ability and taste-for-work parameters of each spouse) that are unobserved by the principal (the government which maximizes social welfare). They find that, under certain assumptions, optimal incentive schemes feature negative jointness, which is consistent with our findings for Europe. Recent papers by Brett (2006) and Cremer, Lozachmeur and Pestieau (2006) also analyze the optimal taxation of couples as a multidimensional screening problem. The rest of the literature (e.g. Schroyen, 2003; Alesina and Ichino, 2007) typically restricts the tax function to be separable (albeit gender-specific), thereby sidestepping the complexities associated with multidimensional screening.

Our paper may be seen as an applied counterpart to these recent theoretical papers. By focusing on small reforms rather than the optimal system, we are able to set out a tractable analysis based on more general and realistic labour supply models than the very stylized models previously considered.

The paper proceeds as follows. Section 2 describes the data and the EUROMOD model. Section 3 maps out the existing tax-transfer treatment of married couples in our sample of European countries. Section 4 sets out a joint labour supply model to evaluate reforms affecting married couples, and presents a microsimulation study of specific reforms that reduce the tax burden on second-earner participation. Section 5 studies marriage penalties, and Section 6 concludes.

\section{Data}

Our data source is EUROMOD, a microsimulation model for the EU built around partly homogenized micro datasets that include data on earnings, labour force participation and demographics. The version 
available for this study relates to 1998 and covers the 15 countries that constituted the EU at that time. Based on detailed algorithms capturing the full range of institutional features of tax and transfer systems in each country, the model is able to compute a wide range of taxes and benefits for each observation unit in representative samples for the various countries. The main policy instruments incorporated in EUROMOD are income taxes, social security contributions (or payroll taxes) paid by employees, benefit recipients, and employers as well as universal and means-tested social benefits including housing assistance. ${ }^{4}$ The model fully accounts for the complicated interaction of different types of taxes and benefits with earnings, assets, employment status, marital status, housing situation and children, and its considerable level of detail makes it an ideal tool for comparative tax analysis. ${ }^{5}$

We restrict the sample to married couples where both husband and wife are between 16 and 64 years of age, where the couple as a whole reports positive annual earnings, and where at least one member of the household has been working the entire year. We exclude those who are currently receiving pension, early retirement, or disability benefits. In each couple, we define the primary earner (PE) as the highest-earning member and the secondary earner (SE) as the lowest-earnings member of the household. Together with our sample restriction, this implies that, in one-earner couples, the primary earner works the entire year while the secondary earner is non-employed throughout the year. In two-earner couples, the secondary earner works either part of or the entire year but always has relatively low earnings.

While we feel that it makes sense to define primary versus secondary earner in terms of earnings (and indirectly labour market participation), the earnings-based definition is in practice highly correlated with a gender-based definition. To demonstrate this, Table 1 displays the share of women among secondary earners according to our definition. We see that, in one-earner couples, more than 90 percent of secondary earners (non-participants) are women in all countries except the Nordic countries and the United Kingdom. In two-earner couples, the second-earner definition is slightly less skewed towards women, so that on average the share of secondary earners that are women varies between 80 and 90 percent across most of the 15 countries in our sample. The close relationship between relative earnings within families and gender implies that a purely earnings-based couple tax function can be targeted to gender without being formally

4. In the results reported here, we do not include unemployment insurance (UI) benefits in the calculation of effective participation tax rates. This is due in part to difficulties associated with accounting properly for the implications of limited UI duration in our static tax rate measures. At a more conceptual level, it is likely that UI schemes providing insurance against involuntary and temporary job loss have very different incentive implications than poverty alleviation programs offering permanent income guarantees to all nonworkers.

5. For further information on EUROMOD, the reader is referred to Sutherland (2001) as well as the Internet at http://www.iser.essex.ac.uk/msu/emod 
gender-based, avoiding discrimination based on a birth characteristic and the legal-constitutional issues this would raise. ${ }^{6}$

\section{The Tax-Transfer Treatment of Couples in Europe}

Based on EUROMOD, this section maps out the tax-transfer treatment of married couples in our sample of European countries. As general background, Tables A1 and A2 in the appendix summarize the most important institutional features of tax and benefit systems affecting married couples in each country.

It is useful to start by distinguishing between two different properties of a tax-transfer schedule for couples: (i) the relative tax rates on husbands and wives, and (ii) the jointness of the schedule. In most of the existing literature, these two properties have been studied as if they are one and the same, with joint taxation being defined as a situation with identical marginal tax rates on the two spouses and individual taxation being defined as a situation with a higher marginal tax rate on the primary earner. However, this close relationship between relative tax rates and jointness is present only under very strong restrictions on the tax schedule. In general, jointness is related to the cross-relationship between tax rates and spousal earnings (a cross-derivative in the tax function), whereas tax rates reflect the relationship between tax liability and own earnings (an own-derivative in the tax function). In principle and in practice, it is entirely possible to combine forms of jointness with, say, lower tax rates on secondary earners.

To make the discussion precise, it is helpful to define the tax function for couples as $T\left(z_{p}, z_{s}\right)$, where $z_{p}$ denotes primary earnings and $z_{s}$ denotes secondary earnings. Below we often refer to this as a tax function', but we want to think of $T($.$) as the net payment by a couple to the government embodying taxes$ as well as transfers. The effective marginal tax rates (including benefit phase-out) of the two spouses are

given by $T_{p}^{\prime}\left(z_{p}, z_{s}\right)$ and $T_{s}^{\prime}\left(z_{p}, z_{s}\right)$, and they are of course important for determining hours worked for those who are working (the intensive margin of labour supply). Marginal tax rates are shown in Table A3 in the appendix, but this section focuses instead on a different tax rate measure - the participation tax rate. This is a more interesting tax rate measure because the extensive margin of labour supply is empirically more important. We define the participation tax rate on a particular family member as the total change in $T($.) as this family member enters into employment as a share of earnings generated by the entry. In order to calculate participation tax rates, one has to make assumptions about the sequence of participation

6. Despite the economic equivalence between gender-based taxation and affirmative action (which has been approved by the courts on many occasions), the two policies would be viewed very differently by the courts. See Rubenfeld (1997) for a discussion of this point in the context of race. 
choices within the household because, with jointness in the tax-transfer code, the tax liability change associated with a person entering depends on whether the spouse is working or not. We make the natural assumption that the primary earner enters first and the secondary earner enters second. In Section secreform theory, we provide a microfoundation for this model, which has been adopted in many empirical labour supply studies (e.g. Eissa, 1995; Eissa and Hoynes, 2004).

Under the assumed sequence of labour market entries in the household, the participation tax rates on the primary and secondary earners are given by

$$
\tau_{p} \equiv \frac{T\left(z_{p}, 0\right)-T(0,0)}{z_{p}}, \quad \tau_{s} \equiv \frac{T\left(z_{p}, z_{s}\right)-T\left(z_{p}, 0\right)}{z_{s}} .
$$

These tax rates are simulated by EUROMOD in the following way. For the computation of $\tau_{s}$, we consider the subsample of two-earner couples and start by computing actual taxes net of transfers $T\left(z_{p}, z_{s}\right)$ at each observed earnings pair, accounting for other relevant household information (place of residence, number of kids, etc.). We then recompute taxes and transfers in the alternative (hypothetical) situation where the secondary earner does not work, $T\left(z_{p}, 0\right)$, and calculate $\tau_{s}$ as in eq. (1). Analogously for $\tau_{p}$, we use the sample of one-earner couples to simulate taxes net of transfers in the original situation, $T\left(z_{p}, 0\right)$, and in the alternative situation where the primary earner is not working, $T(0,0)$, and then apply formula (participation tax rates). ${ }^{7}$

Table 2 shows participation tax rates and labour market outcomes for primary and secondary earners in each country (averages for each country sample). As one would expect, Scandinavia and NorthernContinental Europe feature higher overall tax rate levels than Anglo-Saxon and Southern European countries. More interestingly, the tax rate on primary earners is higher than on secondary earners in all but the four Southern European countries (Greece, Italy, Portugal, and Spain). This is a result of the impact of family-based and means-tested welfare benefits, which are affected more by the first than by the second entrant. We do not observe the same effect in Southern Europe where welfare benefits are less generous.

7. Our tax-rate estimates are therefore calculated for those currently working. As a result of sample selection, one would expect tax rates to be different for non-working individuals considering a transition into work. As we do not observe the earnings potential of non-working individuals, calculating their participation tax rates would require jointly estimating a wage and participation model for couples. In the microsimulation exercise in Section 4, we deal with the selection issue indirectly by considering a decreasing profile of participation elasticities such that new labour market entrants tend to be located at the bottom end of the income distribution. 
Although most countries impose a higher participation tax rate on the primary earner, there are substantial differences in the relative rates across countries. In particular, the UK system stands out by being much more favourable to second-earner participation than all other countries.

The ratio of the primary-earner tax rate to the secondary-earner tax rate is interesting because it can be compared to optimal tax rules expressing relative tax rates as a function of elasticities (e.g. Boskin and Sheshinski, 1983; Kleven and Kreiner, 2006). In the special case of separability in utility of spousal labour supplies, the optimal tax rate on each spouse is given by an inverse elasticity rule and the optimal relative tax rate $\tau_{p} / \tau_{s}$ is therefore given by the participation elasticity of the secondary earner relative to the primary earner. This implies that the tax ratios in the table can be seen as critical values for relative participation elasticities. For example, in the United Kingdom, if the second-earner elasticity is more than 2.79 times as high as the primary earner elasticity, it would be efficient to shift some of the tax burden from secondary earners to primary earners. In view of the evidence on the responsiveness of labour force participation of married women, the table seems to suggest that in many countries the relative tax rate on secondary earners is inefficiently high. We return to this issue in Section 4.

Finally, the table shows that both participation and earnings (conditional on participation) tend to be strongly skewed in favour of primary earners in most countries. Although the countries we consider differ along many dimensions (besides tax rates) that may have direct implications for labour market outcomes, it is interesting that the cross-country variation in relative participation is roughly consistent with the variation in relative participation taxes. For example, Southern European countries are characterized by lower participation taxes along with higher participation rates for primary relative to secondary earners compared to most other countries. At the other end of the spectrum, Denmark, Finland, and the UK are associated with higher relative tax rates and lower relative participation for primary earners.

Let us now consider the jointness of the couple tax function $T\left(z_{p}, z_{s}\right)$ and therefore the cross-derivative $T_{p s}^{\prime \prime}$. One benchmark case is that of fully individual taxation, i.e. $T\left(z_{p}, z_{s}\right)=T_{p}\left(z_{p}\right)+T_{s}\left(z_{s}\right)$, which is associated with a zero cross-derivative $T_{p s}^{\prime \prime}=0$. In practice, the functional forms $T_{p}($.$) and T_{s}($.$) would$ typically be the same, in which case we have a so-called anonymous individual tax. Another benchmark case is the fully joint couple tax $T\left(z_{p}+z_{s}\right)$ as adopted in the United States and in some European countries (see Table A1). If the system additionally features a progressive marginal tax rate structure ( $T^{\prime \prime}>0$ ), the couple tax would be associated with a positive cross-derivative $T_{p s}^{\prime \prime}>0$. More generally, there is a whole range of joint couple tax functions $T\left(z_{p}, z_{s}\right)$ with $T_{p s}^{\prime \prime} \neq 0$. Kleven, Kreiner, and Saez 
(2007) define positive jointness as a system where the tax on one person depends positively on spousal earnings ( $T_{p s}^{\prime \prime}>0$ ), and negative jointness as a system where the tax on each partner depends negatively on spousal earnings $\left(T_{p s}^{\prime \prime}<0\right)$. Because a fully joint schedule is associated with positive jointness, individual taxation can be seen as an intermediate (rather than polar) case in between full jointness and negative jointness. This is interesting because we show below that many real-world schedules feature negative jointness, implying that they have moved further away from fully joint taxation than the individual system.

The above definitions of jointness are stated in terms of cross-derivatives of marginal tax rates. Consistent with the analysis of tax rate levels, we will state a definition of jointness in terms of participation tax rates. In particular, we say that a system is positively joint if $\frac{\partial \tau_{s}}{\partial z_{p}}>0$, negatively joint if $\frac{\partial \tau_{s}}{\partial z_{p}}<0$, and separate if $\frac{\partial \tau_{s}}{\partial z_{p}}=0$. While the definitions of jointness in terms of marginal tax rates are local, the definitions in terms of participation ('average') tax rates reflect that a tax schedule is joint on average over a range of incomes.

Before turning to the empirical results, it is helpful for a moment to separate the tax and transfer system. Denote by $t\left(z_{p}, z_{s}\right)$ the tax payment and by $b\left(z_{p}, z_{s}\right)$ the benefit payment, so that $T\left(z_{p}, z_{s}\right)=t\left(z_{p}, z_{s}\right)-b\left(z_{p}, z_{s}\right)$. Consider then a tax-transfer scheme that combines an individual income tax and a fully joint transfer system, i.e. $T\left(z_{p}, z_{s}\right)=t_{p}\left(z_{p}\right)+t_{s}\left(z_{s}\right)-b\left(z_{p}+z_{s}\right)$. The definition in eq. (1) then implies $\tau_{s}=\left\lfloor t_{s}\left(z_{s}\right)+b\left(z_{p}\right)-b\left(z_{p}+z_{s}\right)\right\rfloor / z_{s}$. Means-testing corresponds to $b\left(z_{p}\right)-b\left(z_{p}+z_{s}\right) \geq 0$, which creates an extra tax on second-earner participation. However, as $z_{p}$ increases, the family is pushed beyond the phase-out range of the various transfer programs (at any given $z_{s}$ ), which tends to lower $b\left(z_{p}\right)-b\left(z_{p}+z_{s}\right)$ and create a pattern where $\frac{\partial \tau_{s}}{\partial z_{p}}<0$ at the bottom. This explains a pattern we find for many countries.

For our measurement of jointness, we construct a number of hypothetical households that vary with respect to household earnings and the number of children, and apply EUROMOD to calculate effective tax rates for these hypothetical families. ${ }^{8}$ We base this part of the analysis on hypothetical households (instead of data on actual households) in order to adequately isolate the interdependence between spouses in the tax-

8. Because we are working with hypothetical households, it is necessary to make an assumption about the living arrangements of the families. We have chosen to assume that all families reside in rental housing, and have then imputed rental costs for all countries. 
benefit legislation. If we were to use sample data and compare the net-tax burden of actual households at different earnings levels, the results would be affected by selection effects. ${ }^{9}$

To illustrate the jointness in the tax-transfer system, we plot the participation tax rate of married individuals at different income levels as a function of the earnings of the spouse. ${ }^{10}$ We consider married individuals at four different income levels: the 5th, 10th, 50th, and 90th percentiles of the earnings distribution of secondary earners (denoted below by SEp5, SEp10, SEp50, and SEp90). For each of these individual income levels, we calculate the participation tax rate at 20 different earnings levels of the spouse, corresponding to the 5th, 10th, 15th,..., 100th percentiles in the earnings distribution of primary earners (denoted below by PEp5, PEp10, ..., PEp100). Our results are shown in Figure 1 for families with two children. Corresponding graphs for childless couples are provided in Figure A2 in the appendix. ${ }^{11}$

The most striking result is that most countries display substantial negative jointness at the bottom of the income distribution. As explained above, this can be largely attributed to means-tested benefits such as social assistance, housing benefits and child benefits that are phased-out as a function of total household income. ${ }^{12}$ Indeed, the high claw-back rates used in many countries tend to generate participation taxes that are very high for secondary earners married to low-wage primary earners, often above $70 \%$ and sometimes close to $100 \%$.

Countries with negative jointness at low income levels may be divided into two groups depending on the pattern at higher income levels. Countries that operate an individual income tax (possibly apart from some family-based tax expenditures at the bottom) and/or have a fairly flat tax rate structure at the top tend to

9. For instance, marriage patterns are known to display positive assertative matching, which in itself would tend to produce a positive relationship between individual tax rates and spousal earnings.

10. For completeness, Figure A1 in the appendix illustrates jointness based on marginal tax rates. The qualitative results are similar to those presented below, but participation tax rate measures are smoother because they reflect average jointness of marginal tax rates over a range of incomes.

11. When considering a couple with one spouse belonging to the bottom of the earnings distribution for primary earners and the other spouse located at the top of the earnings distribution for secondary earners, it may actually be the second spouse who has the highest earnings. This is, however, only relevant for the lower part of the two grey curves because the earnings of the secondary earners in the data are substantially lower than primary earnings. Moreover, the slopes of the curves still reveal the type of jointness at these earnings combinations.

12. In Germany and Belgium, there is an initial slight increase in the second-earner tax rate at low levels of primary-earner income provided that the secondary earner also enters at a low earnings level. This is because these countries employ an earnings disregard in the transfer system, so that the lowest-income families are not affected by benefit withdrawal. 
converge towards no jointness as the income of the primary earner becomes high. ${ }^{13}$ Austria, Denmark, Finland, Sweden and the United Kingdom display this pattern, which we may label negative-neutral jointness. The strongest example of this pattern is perhaps the United Kingdom where negative jointness at the bottom is driven by both the welfare and the tax system. The Working Families Tax Credit (WFTC), an in-work cash benefit provided through the tax system, is based on household income and is phased out at a rate of $70 \%$. The combination of the WFTC and the withdrawal of social assistance and housing benefits creates participation tax rates at around $70-90 \%$ for secondary earners married to low-income spouses. While second-earner participation in the UK is therefore strongly discouraged in low-income families, it is encouraged in higher-income families due to the individual income tax. In particular, because working spouses with low earnings are not liable to pay either income tax or social insurance contributions, the second-earner tax rate at SEp5 and SEp10 drops to zero once primary-earner income exceeds PEp30 and stays at zero as primary earnings increase.

Another group of countries combine negative jointness at the bottom with positive jointness at the top. Countries with this pattern of negative-positive jointness are Belgium, France, Germany, Ireland, Luxembourg and Portugal. All of these countries operate a progressive tax system based on family income causing the secondary-earner participation tax to be increasing in primary-earner income once the family is beyond the phase-out range of welfare programs. However, the degree of positive jointness at the top is generally quite weak and much less salient than the negative jointness at the bottom. This may seem surprising but can be explained by the fact that the effective marginal tax rate structure is quite flat in most European countries, partly as a result of often very substantial social security contributions, which are all based on individual earnings and therefore dampen the jointness of the system as a whole (see Table A1). As explained above, a completely linear tax system, even if it is based on family income, effectively implies separability in the tax treatment of spouses. Notice also that, in France, the curve is relatively flat both at the bottom and at the top because the withdrawal of various family benefits and housing assistance occurs at different income levels and tends to offset the presence of positive jointness in the income tax. ${ }^{14}$

13. Notice that a flat (linear) income tax, even if it is based on family income, effectively implies separability in the tax treatment of spouses. As an example, this is important for Denmark, which operates a form of joint taxation by combining individual filing with the possibility of transferring certain allowances and exemptions across spouses. However, because the marginal tax rate structure is quite flat there is very little jointness at the top.

14. In France, the drop in the participation tax rate for low-wage secondary earners (at SEp10) when the primary-earner income becomes very high (at PEp95) is due to complicated features of the income test for family benefits (Allocations Familiales) that were in place only in 1998, the year of our sample. 
Greece, Italy, and to some extent the Netherlands are the only countries that show virtually no jointness. All three countries operate individual income tax systems, and in Greece and Italy only very limited means-tested benefits are available. ${ }^{15}$ The Netherlands does offer family-based social assistance, but primary earnings are higher in the Netherlands than in most other countries, implying that transfer phaseout plays a limited role for second-earner labour market entry. ${ }^{16}$ Spain is the only country characterized by positive jointness. There is no social assistance and the design of the Spanish income tax implies that, for low-income families, it is optimal to file under the optional joint tax. For higher-income families, it is typically optimal to file separately, which explains why there is less jointness if the secondary earner is at the median or above.

\section{A Welfare Evaluation of Cutting Taxes for Secondary Earners}

It is often argued that the tax burden on secondary earners should be reduced in order to increase economic efficiency. Indeed, a traditional Ramsey-type efficiency argument calls for a low marginal tax rate on secondary earners because their labour supply is relatively elastic (Rosen, 1977; Boskin and Sheshinski, 1983). The traditional argument is derived in a model with only hours-of-work responses and where the tax system is restricted to be linear (albeit gender specific). However, the modern empirical labour supply literature shows that the strong responsiveness of the labour supply of married females is driven by labour force participation, not by hours worked for those who are working (e.g. Heckman, 1993; Blundell and MaCurdy, 1999). This calls for a policy that reduces the participation tax rate on secondary earners.

A policy change should be evaluated, not just in terms of efficiency, but also with respect to its consequences for distributional equity. A revenue-neutral reform reducing the participation tax rate on secondary earners necessarily implies a redistribution in favour of two-earner couples at the expense of one-earner and/or zero-earner couples. To the extent that two-earner couples are better off than zero- and one-earner couples such reforms come at the cost of a reduction in distributional equity. While the statement that two-earner couples are better off than zero-earner couples seems noncontroversial, the comparison between one- and two-earner couples is more subtle. Notice first that, for a given level of primary earnings, the notion that two-earner couples are better off than one-earner couples is consistent

15. In Greece, no means-tested benefits are available for married couples. In Italy, such benefits are very limited, especially for couples without kids as reflected by the almost completely flat curve (in appendix) for those couples. Further, family benefits in Italy are phased-out in discrete amounts at different income levels, which accounts for the small bumps visible for low-income families.

16. The small bump around PEp40 reflects mandatory health insurance contributions for non-working spouses that apply to primary earners with earnings below a certain threshold. Above this earnings level, health insurance contributions for non-working spouses are voluntary and hence not counted as taxes. 
with the underlying assumption in all of the optimal income tax literature that higher household income is a signal of higher utility. ${ }^{17}$ Whether two-earner couples are better off on average depends also on the sorting in the marriage market. Positive sorting in earnings (such that two-earner couples tend to have higher primary-earner income along with the presence of secondary-earner income) reinforces the view that twoearner couples are better off. On the other hand, if there is negative sorting whereby rich people tend to have non-working spouses, it is theoretically possible that one-earner couples are better off on average. However, as shown by Kleven, Kreiner, and Saez (2008) for the UK, there is a positive correlation in spousal earnings (conditional on working) combined with a very weak correlation between primary-earner income and spousal labour force participation. All this suggests that two-earner couples are better off, so that lowering the participation tax on secondary earners comes at a cost of distributional equity.

In this section, we start by setting out a simple "extensive" labour supply model allowing us to evaluate the efficiency-equity trade-off for reforms aimed at increasing second-earner participation. In particular, we consider small (marginal) tax reforms, which provide a transfer to two-earner couples financed by either a tax on both zero- and one-earner couples or a tax on one-earner couples only. The taxes and transfers implemented by the reforms are lump sum conditional on family participation status and therefore do not affect marginal tax rates. Reforms of this type could, e.g., be implemented in practice by changing the structure of family allowances. At the end of the section, we generalize the labour supply model to incorporate both intensive and extensive responses for both spouses, and consider reforms that reduce the tax burden on secondary earners by changing marginal tax rates.

\section{1. $\quad$ A Simple Joint Labour Supply Model}

We consider couples where each spouse decides whether or not to work, but where hours worked conditional on working are fixed. Labour force participation varies across couples due to heterogeneity in earnings potential and work costs, and households can be grouped into three different categories: noearner, one-earner, and two-earner couples. In each household, we identify a primary earner and a secondary earner where, by definition, the primary earner enters the labour market first and has higher earnings conditional on working. Each spouse is characterized by a fixed earnings potential, which we denote by $\left(z_{p}^{h}, z_{s}^{h}\right)$ for the two spouses in a household of type $h$. Letting $z_{i}(i=p, s)$ denote the actual earnings choice, the participation choice for each spouse then amounts to choosing between $Z_{i}=0$ and

17. In the presence of general non-linear tax instruments, the relevant comparison for the determination of the optimal tax on secondary entry is indeed between different types of couples at a given level of primary earnings (Kleven, Kreiner, and Saez, 2007). 
$z_{i}=z_{i}^{h}$. The number of households of type $h$ is denoted $N_{h}, h=1, \ldots, H$, and the total population of households equals $N \equiv \sum_{h=1}^{H} N_{h}$.

All households share a common quasi-linear utility function given by

$$
u\left(c, z_{p}, z_{s}\right)=c-q_{p} \cdot 1\left(z_{p}>0\right)-q_{s} \cdot 1\left(z_{s}>0\right)
$$

where $c$ is household consumption, and $q_{p}, q_{s}$ denote work costs for the primary and secondary earner, respectively. The work costs capture all costs associated with labour market entry such as a distaste for participation, the value of lost home production, costs of child care and commuting, etc. The indicator function $1($.$) takes on the value 1$ when a given spouse works ( $z_{i}>0, \quad i=p, s$ ) and zero otherwise. The above utility specification rules out income effects which simplifies considerably the theoretical analysis (Kleven, Kreiner, and Saez, 2007, 2008) as well as the welfare aggregation.

The household faces a non-linear income tax schedule $T\left(z_{p}, z_{s}, \theta\right)$, where $\theta$ is a shift parameter that we use below to capture the effects of a tax reform. The tax function constitutes a net payment to the public sector, embodying both taxes and transfers. The consumption of each household equals their total net-oftax earnings, such that eq. (2) can be written as

$$
u=z_{p}+z_{s}-T\left(z_{p}, z_{s}, \theta\right)-q_{p} \cdot 1\left(z_{p}>0\right)-q_{s} \cdot 1\left(z_{s}>0\right) .
$$

Households choose earnings $z_{p}$ and $z_{s}$ so as to maximize eq. (3). For households of type $h$ (i.e., earnings pair $z_{p}^{h}, z_{s}^{h}$ ), there is a distribution of fixed costs described by a continuous joint density function $f_{h}\left(q_{p}, q_{s}\right)$ defined over $[0, \infty) \times[0, \infty)$. We define the unconditional density and distribution functions of $q_{p}$ as $f_{h}\left(q_{p}\right)$ and $F_{h}\left(q_{p}\right)$, and the conditional density and distribution functions of $q_{s}$ as $p_{h}\left(q_{s} \mid q_{p}\right)$ and $P\left(q_{s} \mid q_{p}\right)$, and hence the joint density can be written as $f_{h}\left(q_{p}, q_{s}\right)=p_{h}\left(q_{s} \mid q_{p}\right) \cdot f_{h}\left(q_{p}\right)$.

Consistent with much empirical work in this area, we consider households making a sequential labour force participation decision. First, it is decided whether or not the primary earner should enter the labour market and then, conditional on primary-earner participation, it is decided if the secondary earner should join the labour force as well. We need to ensure that the assumed entry sequence is consistent with household optimization, which amounts to a restriction on the joint distribution of fixed work costs. Figure 
2 illustrates the problem by depicting the possible joint labour supply choices of the two spouses. The crucial assumption we make is that, both before and after a tax reform, couples are observed only in the shaded areas (0,1 and 2). The part of the assumption that concerns the initial (before-reform) distribution of couples is innocuous, because we simply define the primary earner (i.e., the highest-earning spouse) in such a way that it is consistent with the permissible pattern. However, when we consider tax reforms that induce families to change participation status, we must make sure that no families move to region $\varnothing$ in the figure. This problem is reminiscent of the double-deviation problem in optimal multi-dimensional pricing theory (e.g. Armstrong and Rochet, 1999) and in the theory of optimal taxation with more than one dimension of unobserved household characteristics (e.g. Mirrlees, 1976, 1986; Kleven et al., 2007). While the double-deviation problem poses considerable complexity for studies that attempt to solve for the optimal incentive scheme in a multi-dimensional screening context, it is easier to deal with the issue here because we consider only small perturbations (marginal reforms) around an initial equilibrium. Appendix A shows how we deal with the double-deviation issue by imposing restrictions on the distribution of fixed costs.

Given the assumed sequence of labour market entries, a primary earner decides to enter if the net household utility gain of doing so, conditional on spousal non-participation, is positive. For household $h$, this implies

$$
q_{p} \leq z_{p}^{h}-\left[T\left(z_{p}^{h}, 0, \theta\right)-T(0,0, \theta)\right] \equiv \bar{q}_{p}^{h},
$$

where $\bar{q}_{p}^{h}$ is the net-of-tax income gain of primary-earner entry for household type $h$. Primary earners with $q_{p} \leq \bar{q}_{p}^{h}$ decide to enter the labour market at $z_{p}=z_{p}^{h}$, whereas primary earners with $q_{p}>\bar{q}_{p}^{h}$ stay outside the labour force. Conditional on primary-earner entry, the secondary earner in household $h$ enters if

$$
q_{s} \leq z_{s}^{h}-\left[T\left(z_{p}^{h}, z_{s}^{h}, \theta\right)-T\left(z_{p}^{h}, 0, \theta\right)\right] \equiv \bar{q}_{s}^{h},
$$

where $\bar{q}_{s}^{h}$ is the net-of-tax income gain of second-earner entry.

Let $\quad E_{0}^{h}=N_{h}\left[1-F_{h}\left(\bar{q}_{p}^{h}\right)\right], \quad E_{1}^{h}=N_{h} F_{h}\left(\bar{q}_{p}^{h}\right)-E_{2}^{h} \quad$ and $\quad E_{2}^{h}=N_{h} \int_{0}^{\bar{q}_{p}^{h}} P_{h}\left(\bar{q}_{s}^{h} \mid q_{p}\right) f_{h}\left(q_{p}\right) d q_{p} \quad$ denote, respectively, the number of zero-earner, one-earner, and two-earner couples of type $h$. Consistent with 
our assumed sequence of labour market entry, we define the participation elasticities for primary and secondary earners as

$$
\eta_{p}^{h} \equiv \frac{\partial E_{1}^{h}}{\partial\left[z_{p}^{h}\left(1-a_{p}^{h}\right)\right]} \frac{z_{p}^{h}\left(1-a_{p}^{h}\right)}{E_{1}^{h}}, \eta_{s}^{h} \equiv \frac{\partial E_{2}^{h}}{\partial\left[z_{s}^{h}\left(1-a_{s}^{h}\right)\right]} \frac{z_{s}^{h}\left(1-a_{s}^{h}\right)}{E_{2}^{h}},
$$

where $a_{p}^{h} \equiv\left[T\left(z_{p}^{h}, 0, \theta\right)-T(0,0, \theta)\right] / z_{p}^{h}$ is the participation tax rate for primary earners in household type $h$, and $a_{s}^{h} \equiv\left[T\left(z_{p}^{h}, z_{s}^{h}, \theta\right)-T\left(z_{p}^{h}, 0, \theta\right)\right] / z_{s}^{h}$ is the participation tax rate for secondary earners.

Because no households are observed with only the secondary earner working, government revenue can be written as

$$
R=\sum_{h}\left\lfloor T\left(z_{p}^{h}, z_{s}^{h}, \theta\right) E_{2}^{h}+T\left(z_{p}^{h}, 0, \theta\right) E_{1}^{h}+T(0,0, \theta) E_{0}^{h}\right\rfloor
$$

which is simply the sum of the tax proceeds (net of transfers) from two-earner families (first term), one-earner families (second term), and zero-earner families (third term).

\subsection{A Microsimulation Study of Reform}

This section studies the effects of small tax reforms, $d \theta$, that reduce the tax burden on second-earner participation, $\partial a_{s}^{h} / \partial \theta<0$, and are revenue-neutral, $d R / d \theta=0$. As explained above, such reforms necessarily imply a redistribution in favour of two-earner couples at the expense of one- and zero-earner couples, and are therefore associated with a trade-off between equity and efficiency.

We derive theoretical measures of the equity-efficiency trade-offs associated with two specific reforms as a function of behavioural elasticities and parameters of the tax-transfer system, and apply the analytical results to our samples of married couple populations in 15 EU countries using EUROMOD.

Following Browning and Johnson (1984) and Immervoll et al. (2007), we divide the population into those who gain from the reform and those who lose from the reform. We denote by $d G \geq 0$ the aggregate welfare gain of those who gain from the reform and by $d L \leq 0$ the aggregate welfare change of those who loose from the reform. Notice that a Pareto improving reform (no losers) implies $d L=0$, whereas a Pareto worsening reform (no gainers) implies $d G=0$. 
Due to the efficiency effects of changing distortionary taxes and transfers, the decline in welfare for those who lose from the reform (i.e., zero- and one-earner couples) is generally different from the gain in welfare for those who gain from the reform (i.e., two-earner couples). In particular, because we consider reforms designed to increase efficiency by subsidizing second-earner participation, we would expect that the gain for two-earner couples is higher than the loss for zero- and one-earner couples. At the same time, because two-earner couples tend to be better off than the rest of the population, policy makers may put a lower social welfare weight on the gain for two-earner couples. A critical question then becomes how to evaluate the desirability of reforms involving such inter-household utility trade-offs. The standard approach has been to postulate a social welfare function associated with certain welfare weights across different households, but the problem is that the inter-household comparisons implied by the adopted social welfare function are subjective and this limits the applicability of such an analysis as an input into the policymaking process. Following Immervoll et al. (2007), we therefore adopt a different approach, which consists in estimating critical values for the social welfare weights that would make a reform break even in terms of social welfare.

To make this precise, we define the inter-household utility trade-off $\Psi$ in the following way:

$$
\Psi=-\frac{d L}{d G}
$$

The resulting number may be interpreted as the Euro-value of the welfare loss for those who lose from the reform (zero- and one-earner couples) per additional Euro transferred to those who gain (two-earner couples). If the reform succeeds in increasing efficiency ( $d L+d G>0$ ), the value of $\Psi$ is below 1 , implying that it costs less than one Euro for zero-earner and one-earner couples to transfer an additional Euro to two-earner couples. However, to the extent that the social marginal welfare weight on two-earner couples relative to other couples is below one, $\Psi<1$ does not necessarily make the reform desirable. Generally, the lower is $\Psi$, the more desirable is the reform, and if $\Psi=0$ the reform represents a Paretoimprovement.

The first reform (Reform A) reduces tax rates on secondary earners by uniformly lowering the tax burden on two-earner couples financed by uniformly increasing the tax burden on zero- and one-earner couples. The size of the extra tax on zero- and one-earner couples is determined endogenously to balance the government budget taking into account the revenue implications of behavioural responses. The reform increases second-earner participation, but has no effect on primary-earner incentives to enter the labour 
market as the tax increase is uniform across households with one earner and no earners. The trade-off measure for Reform A may be derived as (see Appendix A)

$$
\Psi_{A}=\frac{1-\sum_{h} e_{2}^{h} \frac{a_{s}^{h}}{1-a_{s}^{h}} \eta_{s}^{h}}{1+\frac{e_{2}}{1-e_{2}} \sum_{h} e_{2}^{h} \frac{a_{s}^{h}}{1-a_{s}^{h}} \eta_{s}^{h}}<1,
$$

where $e_{2}$ is the share of two-earner couples in the total population of couples, and $e_{2}^{h}$ is the share of two-earner couples that are of type $h$. This type of reform is always associated with an inter-household trade-off $\Psi$ below 1: the increase in second-earner participation (at unchanged primary-earner participation) raises revenue, implying that the government can finance a welfare increase of one Euro to two-earner couples by imposing a welfare cost of less than one Euro on all other couples. It is clear from eq. (6) that the key determinants of the inter-household trade-off are the participation tax rates and participation elasticities of secondary earners, and that $\Psi$ is decreasing in $a_{s}^{h}$ and $\eta_{s}^{h}$ as one would expect.

The second reform (Reform B) finances the tax cut on two-earner couples by taxing only one-earner couples, thereby avoiding a reduction in the welfare of zero-earner families. While reform B is associated with a better distributional profile than Reform A, the efficiency effects may be less desirable for Reform B because it increases participation tax rates on primary earners. The trade-off measure for Reform B can be expressed as (see Appendix A)

$$
\Psi_{B}=\frac{1-\sum_{h} e_{2}^{h} \frac{a_{s}^{h}}{1-a_{s}^{h}} \eta_{s}^{h}}{1-\sum_{h} e_{1}^{h} \frac{a_{p}^{h}}{1-a_{p}^{h}} \eta_{p}^{h}+\frac{e_{2}}{e_{1}} \sum_{h} e_{2}^{h} \frac{a_{s}^{h}}{1-a_{s}^{h}} \eta_{s}^{h}},
$$

where $e_{1}$ is the share of one-earner households in the population, and $e_{1}^{h}$ is the share of one-earner households that are of type $h$. As for the first reform, the trade-off associated with Reform B is decreasing in second-earner participation tax rates and participation elasticities. The trade-off $\Psi_{B}$ additionally depends on primary-earner parameters: higher participation tax rates and higher participation elasticities for primary earners increase the trade-off. This reflects the negative efficiency effect associated with some one-earner couples dropping back to the zero-earner schedule as the tax on one-earner couples increases. Although the negative participation responses of primary earners tend to worsen the trade-off of reform $B$ compared to reform A, there is an offsetting effect that tends to make the reform more desirable. The impact on the second-earner participation incentive is larger for reform B, because it finances the tax cuts 
for two-earner families entirely by higher taxes on one-earner families and therefore has a larger effect on the utility difference between two-earner and one-earner couples. Thus, it is theoretically possible that reform B improves efficiency by more than reform A, and this is more likely to occur if the share of oneearner households $e_{1}$ is low, in which case reform $\mathrm{B}$ leads to a large tax increase for one-earner households.

We now turn to numerical simulations based on EUROMOD. As described, we identify the primary earner as the highest-earning member of the couple, and construct pre-tax earnings distributions for primary and secondary earners. Because the theoretical analysis is based on a discrete formulation dividing the population of couples into $H$ earnings-groups, we have to define these subgroups in the empirical application. We divide the sample based on earnings quintiles (conditional on working) for primary and secondary earners, which yields 30 household groups ( $5 \times 5$ two-earner families and 5 one-earner families). For each household group, we calculate a participation tax rate using the approach described in Section 3.

We calibrate participation elasticities based on the empirical labour supply literature. There is an extensive literature on the labour force participation of married couples based on data from the United States and European countries. This literature has been surveyed by, among others, Blundell (1995) and Blundell and MaCurdy (1999). The literature finds that participation elasticities for married women (secondary earners) are substantial across a wide set of countries with values ranging from 0.5 to 1 , whereas participation elasticities for prime-age males (primary earners) tend to be very small. Moreover, there is evidence that participation elasticities tend to be larger at the bottom of the earnings distribution than at the top of the earnings distribution, although some studies have found that elasticities for married women may still be substantial at the top (e.g. Eissa, 1995).

Results of the simulations are presented in Table 3. We consider four different elasticity scenarios. The first three scenarios assume that the participation elasticities are constant across earnings groups, whereas the last scenario assumes that elasticities are higher at the bottom. Average elasticities for primary and secondary earners are shown in the table for each scenario.

We start by focusing on Reform A. Recall that the inter-household trade-off associated with this reform (eq. psi1) does not depend on the participation elasticity for primary earners, only the elasticity for secondary earners matters. The first scenario assumes a participation elasticity of 0.5 for secondary earners. In this scenario, many countries show a quite favourable trade-off. In Germany, one- and zero-earner couples incur a loss of just 0.14 Euros for an additional Euro distributed to two-earner couples. In Belgium, Denmark, and France, second-earner tax rates are so high that a tax cut to two-earner families creates 
Laffer effects and therefore a Pareto improvement. In general, the favourable trade-offs for this reform and elasticity scenario reflect the high participation tax rates on secondary earners (compared to elasticities) that we saw in Table 2. In accordance with the pattern in Table 2, Reform A is less attractive in Greece, the UK, and Spain than in Northern-Continental European countries and Scandinavia.

Not surprisingly, Reform A becomes better (worse) as the participation elasticity of secondary earners increases (declines). In the second scenario where the second-earner elasticity is set equal to 0.7 , the reform is costless or nearly costless to zero- and one-earner couples in half of the countries (Belgium, Denmark, Finland, France, Germany, Ireland, and Sweden). On the other hand, in the third scenario where the second-earner elasticity is set equal to 0.3 , it is only Belgium that has no losers from the reform. Nevertheless, even in this scenario, nine countries have trade-offs at or below 1/2. Scenario 4 assumes the same average elasticity as in the first scenario but with a declining profile as a function of earnings. ${ }^{18}$ The results do not change much compared to scenario 1, although there is a general tendency for the trade-off measure to increase. The reason is that the positive feedback effect on government revenue from higher participation is lower when the additional participation is generated at lower earnings levels where secondearner participation tax rates are typically lower.

The consequences of Reform B depend also on the primary-earner participation elasticity. In scenario 1, where the primary-earner elasticity is set equal to 0.1 , we see that $\Psi$ increases compared to Reform A but that the differences between the two reforms are small for all countries. Hence, the two counteracting effects on economic efficiency discussed above more or less cancel out in this elasticity scenario. When we look across the different scenarios, the effects of Reform A and B are roughly comparable except for Scenario 3 where we assume equal responsiveness for primary and secondary earners. This scenario is not realistic but highlights the importance of the relative participation elasticities when evaluating reforms of type B that affect zero- and one-earner couples differently. In this scenario, ten countries would experience lower efficiency by implementing reform B (i.e., $\Psi>1$ ), and in seven of those countries nobody gains from the reform (Pareto worsening). The explanation is that, for most countries, primary earners face higher participation tax rates than secondary earners. This implies that, with identical elasticities, that primary-earner labour supply is more distorted than second-earner labour supply, and it is therefore suboptimal to induce additional second-earner entry at the expense of primary-earner exit.

18. The primary-earner elasticity is set equal to 0.3 at the lowest quintile of the primary earner income distribution (PEq1), 0.1 for PEq2 and PEq3, and 0 for PEq4 and PEq5. For secondary earners, the elasticity equals 0.8 for the lowest quintile of the secondary earner income distribution (SEq1), 0.6 for SEq2, 0.2 for SEq3, and 0 for SEq4 and SEq5. 


\subsection{Evaluating Reforms that Affect the Intensive Margin of Labour Supply}

The reforms considered so far shift the tax burden across couples without changing marginal tax rates. Such reforms do not affect the intensive margin of labour supply (in the absence of income effects), and the assumption of fixed hours of work is therefore innocuous in the context of those reforms. But to analyze reforms associated with changes in marginal tax rates, it is necessary to extend the model to allow for both intensive and extensive responses for both spouses. Appendix B extends the model in this way, and derives the effects of a reform (Reform C) that uniformly reduces the marginal tax rate on secondary earners financed by uniformly increasing the marginal tax rate on primary earners in one-earner couples. Zero-earner couples are left unaffected. Like Reform B considered above, the reform considered here shifts participation taxes from secondary earners to primary earners, but the profile of the tax changes is different. Compared to the previous reform, changes in participation taxes are now higher at the top and lower at the bottom.

Table 4 presents the inter-household utility trade-off implied by reform $\mathrm{C}$ for three different elasticity scenarios. In all three scenarios, the participation elasticities are set at our preferred levels of 0.1 for primary earners and 0.5 for secondary earners. To establish a benchmark, the first scenario assumes that hours-of-work elasticities are equal to zero for both spouses. In this case, Reform C is associated with slightly more favourable trade-offs than Reform B. The reason is that the participation tax rates of secondary earners often have an increasing profile (due to the progressivity of the tax system), whereas the participation tax rates of primary earners often display a decreasing profile (due to the impact of meanstested transfers on the first entrant). This implies that reform C (relative to Reform B) concentrates the tax cuts to secondary earners on those with the highest participation tax rates, while it concentrates the tax increases for primary earners on those with the lowest participation tax rates. The second scenario sets the intensive elasticity to 0.1 for both primary and secondary earners. This generates an additional efficiency gain on the intensive margin for secondary earners, but also an efficiency loss from the intensive responses of primary earners. The total effect is that trade-offs are slightly more favourable. Scenario 3 features the same overall responsiveness on the intensive margin as Scenario 2 (the sum of the two elasticities is unchanged), but the response is now concentrated entirely on secondary earners. This makes reform $\mathrm{C}$ even more attractive and five countries (Belgium, Denmark, France, Germany, and Sweden) can implement the reform at no distributional cost.

Our conclusion is that the incorporation of hours-of-work responses into the analysis (assuming realistic elasticities) does not change the qualitative insights offered above and has a fairly small quantitative 
impact. If anything, the conclusions regarding the welfare effects of cutting taxes for secondary earners are reinforced by this generalization.

\section{Marriage Penalties in Europe}

We now turn our attention to the tax-transfer implications of marriage. We present estimates of the marriage penalty defined as the increase in the combined tax liability net of transfers of two individuals following marriage. ${ }^{19}$ The marriage penalty has attracted significant interest historically, especially in the United States where tax acts affecting married couples have often been motivated by an attempt to 'fix' the problem of marriage penalties. The concern about marriage penalties has been motivated by notions of fairness in the tax treatment of families (horizontal equity across married and cohabitating couples), and by the possibility that tax and transfer incentives distort the decision to marry. A number of papers have studied the effects on marriage and divorce from income taxes (e.g. Alm and Whittington, 1995a,b, 1997, 1999), welfare benefits (e.g. Hoynes, 1997a,b; Moffitt, 1998; Bitler et al., 2004), or taxes and benefits combined (Dickert-Conlin, 1999; Eissa and Hoynes, 2000b). Although these studies tend to find either modest or no effects, the implications of marriage disincentives continue to be a controversial point of contention and marriage-dependent taxes and transfers are frequently accused by conservatives of destroying the traditional two-parent family and creating higher rates of single motherhood.

Almost all existing studies of marriage penalties focus on the United States and account only for the implications of the tax system (e.g. Rosen, 1987; Feenberg and Rosen, 1995; Alm and Whittington, 1996; Dickert-Conlin and Houser, 1998; Bull et al., 1999; Alm et al., 1999; Eissa and Hoynes, 2000a). An exception to this strong US-orientation in the literature is the comparative study of marriage taxes by Pechman and Engelhardt (1990) who considered a subset of the European countries in our sample. While Pechman and Engelhardt considered only the tax system, we have seen in this paper that most of the jointness in redistribution schemes in Europe is driven by the welfare system suggesting that there may be important transfer-consequences to marriage. EUROMOD allows us to undertake a comparative study of marriage penalties across a large set of countries, and to incorporate fully the implication of both the tax and the transfer system.

19. While we use the term marriage penalty throughout the paper, it would perhaps be more precise to use the label formal cohabitation penalty. In principle, income transfers are based on family income regardless of marital status, although in practice it is difficult for the authorities to verify cohabitation when there is no marriage certificate. 
It is helpful to start by considering some general properties of marriage penalties. Denoting by $T^{i}($.$) the$ tax function (net of transfers) that applies to individual filers and by $T^{c}($.) the tax function applying to couples, the marriage penalty is defined as

$$
M P \equiv T^{c}\left(z_{p}, z_{s}\right)-\left[T^{i}\left(z_{p}\right)+T^{i}\left(z_{s}\right)\right]
$$

Individual income tax treatment of couples, i.e. $T^{c}\left(z_{p}, z_{s}\right)=T^{i}\left(z_{p}\right)+T^{i}\left(z_{s}\right)$, is the only income tax system that does not introduce a distortion of the marriage decision, $M P=0$. On the other hand, jointness generally implies $M P \neq 0$, and the sign of $M P$ depends on the design of the joint schedule and on the pair of incomes $z_{p}, z_{s}$ in a given family. If $M P$ is negative, we say that there is a marriage subsidy. An example of a tax system giving rise to marriage subsidies (ignoring the welfare system) is a progressive and fully joint tax scheme with income splitting, so that each spouse is liable to pay taxes on half the couple's combined earnings. Formally, this is a system where $T^{c}\left(z_{p}, z_{s}\right)=T^{i}\left(\frac{z_{p}+z_{s}}{2}\right)+T^{i}\left(\frac{z_{p}+z_{s}}{2}\right) \equiv T^{c}\left(z_{p}+z_{s}\right)$. Income splitting subsidizes marriage by allowing a couple to avoid part of the progressivity of the tax system.

Family-based and means-tested transfers generally give rise to marriage penalties. As in Section secjointness, let us separate the $T$-functions into taxes $\left(t^{c}(),. t^{i}().\right)$ and benefits $\left(b^{c}(),. b^{i}().\right)$. The combination of individual taxation and family-based transfers then implies $M P \equiv b^{i}\left(z_{p}\right)+b^{i}\left(z_{s}\right)-b^{c}\left(z_{p}+z_{s}\right)$. Then, if the $b^{i}($.$) and b^{c}($.$) functions are the same (so that marital$ status is not an eligibility criterion in its own right), we have $M P>0$ because $b^{\prime}()<$.0 as a result of means-testing. Moreover, if there is additional targeting to single parents (in which case $b^{c}(z)<b^{i}(z)$ given the presence of children), the marriage penalty is even higher. Because family-based, means-tested transfers as well as targeting to single motherhood tend to be very important at the bottom of the distribution, we would expect to find significant marriage penalties at the bottom. Moreover, these features would be particularly important in countries where welfare systems are relatively generous (such as the Nordic countries). 
The marriage penalty in eq. (8) is calculated using EUROMOD by measuring the change in the combined tax liability net of transfers of a couple following a separation, holding individual earnings constant. ${ }^{20}$ We consider households at ten different earnings configurations, ranging from both spouses being out of work to both spouses earning at the top decile in their respective earnings distributions, and we consider families with either two children or no children. When children are involved, we assume that each spouse takes custody of one child after the divorce. ${ }^{21}$ We also assume that, following the divorce, each spouse faces half the rental cost of the couple when they were married. ${ }^{22}$ The marriage penalties are shown in Table 5 for the case of two children. Table A4 in the appendix shows the results for families without children. Marriage penalties are reported on an annual basis and in 2007 Euros.

The results reveal substantial marriage penalties in most countries, and the penalties depend primarily on the income of the lowest-earning spouse. Indeed, marriage penalties are often very high even when the primary earner is at the top decile as long as second-earner income is low. Moreover, marriage penalties are almost everywhere considerably higher when the couple has children, often more than twice as high. These patterns point to the benefit system as an important determinant of marriage penalties. In fact, in all countries, the strong targeting of transfer programs to single parents is the single most important factor contributing to marriage penalties. The tax system per se is not very important. As a result, the highest marriage penalties are found in countries that have the most generous benefit programs such as the Nordic countries, the Netherlands, France and Germany. Because of highly targeted transfers to single parents, the United Kingdom and Ireland also show substantial marriage penalties for families with children, although their social assistance programs are on the whole less generous than those of the Nordic countries.

There are some exceptions to this general pattern of high marriage penalties. Italy offers non-trivial marriage subsidies resulting from family benefits available only to married couples with children. The tax-

20. Although individual earnings may of course change following a separation, it is conceptually important to keep earnings constant in order to obtain the correct tax price on marriage. Notice that, if earnings were allowed to change at separation, even a fully individual-based redistribution scheme would appear to feature marriage penalties or subsidies.

21. The assumption of a 1-1 split of custody is different from the usual assumptions in the (US-based) literature on marriage taxes. This literature typically assumes that either (i) the children reside with the mother (Dickert-Conlin and Houser, 1998; Eissa and Hoynes, 2000a) or (ii) custody is determined by a tax minimization strategy (Rosen, 1987; Feenberg and Rosen, 1995). Because the second assumption implies that typically the higher-earnings spouse takes custody of all the children, whereas the first assumption implies that typically the lower-earnings spouse gets the kids, our assumption of an equal split lies in between these two extremes.

22. Our approach to the calculation of marriage penalties is closely related to the so-called Resource Pooling Approach (see Bull et al., 1999). Our calculations do not include unearned income and therefore capture only the marriage penalty arising from the tax-transfer treatment of earned income. 
transfer system in Greece is virtually neutral with respect to marriage for couples without children, but does feature minor penalties for couples with children. This is the result of an individual income tax combined with fairly small social assistance benefits that are available only to single parents. Spain tends to subsidize marriage for couples without children but penalize it for couples with children. In France, marriage subsidies are considerable for higher-income families. ${ }^{23}$

\section{Conclusion}

The standard Mirrleesian theory of optimal income taxation assumes that all tax payers and transfer recipients live in single-person households. In reality, most individuals live in families formed around couples, and the tax-transfer rules applying to couples are often different from the rules applying to single individuals. A number of recent papers have attempted to generalize the theory of optimal income taxation to explicitly deal with couples. Instead of characterizing the optimal tax-transfer treatment of families, this paper characterizes the actual tax-transfer treatment of couples and identifies efficiency -improving (and possibly welfare-improving) reforms for 15 European countries.

We have considered three aspects of a tax-transfer system for couples: the form of jointness, the distortion of second-earner labour supply, and the size of marriage penalties. A general insight from the analysis is that the transfer system is a crucial element in understanding and evaluating redistribution schemes affecting married couples. For example, it is the presence of family-based and means-tested transfer programs that explains the observation in many countries of negative jointness, i.e. a negative relationship between the effective tax rate on one person and the earnings of the spouse. Interestingly, negative jointness is in accordance with prescriptions from the recent optimal tax literature (Kleven, Kreiner and Saez, 2007, 2008). At the same time, family-based transfers tend to create substantial marriage penalties at the bottom of the distribution, which raise issues pertaining to fairness and to some extent efficiency.

Our analysis of tax-transfer distortions at the extensive margin of labour supply suggests that the effective taxation of secondary earners relative to primary earners is too high given the empirical evidence on participation elasticities. Simple revenue-neutral reforms that shift some of the tax burden from two-earner couples to one-earner and/or zero-earner couples would reduce the distortion of second-earner labour

23. An additional important factor determining marriage penalties are housing benefits. In results not reported here, we have calculated marriage penalties under alternative assumptions about housing costs following separation. For example, if rental costs for each spouse are at the same level as the combined rental costs of the couple (reflecting economies of scale in two-person households), the size of marriage penalties are considerably affected in some countries (in particular, the UK, Ireland, Germany, Austria, Denmark, Finland, and the Netherlands). 
supply and may generate substantial welfare gains. In fact, for some countries, a tax cut for secondary earners may realistically pay for itself and give rise to a Pareto improvement. For countries where Laffer effects are not present, a tax cut for two-earner families does require a higher tax on other couples, but the required tax increase tends to be reasonably small. In a majority of countries, it is possible to transfer 1 euro to two-earner couples by taking away less than $1 / 2$ a euro from other couples.

\section{APPENDIX A: DERIVATION OF EQUATIONS (6) AND (7)}

We derive the inter-household utility trade-off under the assumption that there are no households with only the secondary earner working either before or after a reform. To ensure that this is consistent with household optimization we must restrict the distribution of the fixed costs of work for secondary earners. In terms of Figure 2, we must make sure that a marginal reform does not induce any families to position themselves in area $\varnothing$. We denote by $V_{h}(\cdot)$ the indirect family utility function, which depends on the work status of the two spouses. The conditions we will impose on the distribution of fixed costs of work for the secondary earner amount to saying that, following a marginal reform, the indirect utility is greater for all families if they are in area 0 of Figure 2 than if they are in area $\varnothing$. A sufficient condition makes sure that no couples have a high fixed cost of work for the primary earner $q_{p}$ and at the same time a relatively low $q_{s}$ for the secondary earner.

Let $\bar{q}_{s}^{h}(0) \equiv V_{h}(0,1)-V(0,0)$ be the gain from secondary earner entry for household type $h$ when the primary earner is not working, and let $\bar{q}_{p}^{h}(1) \equiv V_{h}(1,1)-V_{h}(0,1)$ be the gain from primary earner entry when the secondary earner is already working. Further, let $\underline{q_{p}^{h}} \equiv \min \left\{\bar{q}_{p}^{h}(1), \bar{q}_{p}^{h}\right\}$ where $\bar{q}_{p}^{h}$ is determined by (qar). We will assume a lower bound on the secondary earner fixed costs of work depending on the

primary earner's fixed costs of work, $\underline{q_{s}^{h}}\left(q_{p}\right)$, such that $P_{h}\left(\underline{q_{s}^{h}}\left(q_{p}\right) \mid q_{p}\right) \equiv 0$. The lower bound assumption is

$$
\underline{q_{s}^{h}}\left(q_{p}\right)>q_{s}^{h}(0) \text { for } q_{p}>\underline{q_{p}^{h}} .
$$

The reason for the two different thresholds for the primary earner is that we must consider both the potential movement from area 2 to area $\varnothing$ and from area 0 to area $\varnothing$ in Figure 2 . 
With this assumption, there will be no households with only the secondary earner working either before or after marginal reforms. Government revenue can then be written as

$$
\begin{aligned}
R= & \sum_{h} N_{h}\left[\int_{0}^{\bar{q}_{p}^{h}} \int_{\underline{q_{s}^{h}}\left(q_{p}\right)}^{\bar{q}_{s}^{h}} T\left(z_{p}^{h}, z_{s}^{h}, \theta\right) p_{h}\left(q_{s} \mid q_{p}\right) f_{h}\left(q_{p}\right) d q_{s} d q_{p}\right. \\
& +\int_{0}^{\bar{q}_{p}^{h}} \int_{\bar{q}_{s}^{h}}^{\infty} T\left(z_{p}^{h}, 0, \theta\right) p_{h}\left(q_{s} \mid q_{p}\right) p_{h}\left(q_{s} \mid q_{p}\right) f_{h}\left(q_{p}\right) d q_{s} d q_{p} \\
& \left.+\int_{\bar{q}_{p}^{h}}^{\infty} \int_{q_{s}^{h}\left(q_{p}\right)}^{\infty} T(0,0, \theta) p_{h}\left(q_{s} \mid q_{p}\right) f_{h}\left(q_{p}\right) d q_{s} d q_{p}\right] \\
= & \sum_{h}\left[T\left(z_{p}^{h}, z_{s}^{h}, \theta\right) E_{2}^{h}+T\left(z_{p}^{h}, 0, \theta\right) E_{1}^{h}+T(0,0, \theta) E_{0}^{h}\right]
\end{aligned}
$$

where $E_{2}^{h}$ is the number of two-earner households of type $h$, or equivalently, the number of working secondary earners of type $h, E_{1}^{h}$ is the number of one-earner households of type $h$, and $E_{0}^{h}$ is the number of type $h$ households without any labour force attachment.

The effect of a small reform, $d \theta$, on government revenue is given by

$$
\begin{aligned}
\frac{d R}{d \theta}= & \sum_{h}\left[\frac{\partial T_{h}(1,1)}{\partial \theta} E_{2}^{h}+\frac{\partial T_{h}(1,0)}{\partial \theta} E_{1}^{h}+\frac{\partial T_{h}(0,0)}{\partial \theta} E_{0}^{h}\right. \\
& \left.+T_{h}(1,1) \frac{d E_{2}^{h}}{d \theta}+T_{h}(1,0) \frac{d E_{1}^{h}}{d \theta}+T_{h}(0,0) \frac{d E_{0}^{h}}{d \theta}\right] \\
= & \sum_{h}\left[\frac{\partial T_{h}(1,1)}{\partial \theta} E_{2}^{h}+\frac{\partial T_{h}(1,0)}{\partial \theta} E_{1}^{h}+\frac{\partial T_{h}(0,0)}{\partial \theta} E_{0}^{h}\right. \\
& \left.+\left[T_{h}(1,1)-T_{h}(1,0)\right] \frac{d E_{2}^{h}}{d \theta}+\left[T_{h}(1,0)-T_{h}(0,0)\right]\left(\frac{d E_{1}^{h}}{d \theta}+\frac{d E_{2}^{h}}{d \theta}\right)\right],
\end{aligned}
$$

because

$$
\frac{d E_{0}^{h}}{d \theta}=-\left(\frac{d E_{1}^{h}}{d \theta}+\frac{d E_{2}^{h}}{d \theta}\right) .
$$

The first three terms in (A-3) reflect mechanical effects while the last two terms capture the effects of the behavioural responses. The mechanical revenue effects are simply the direct effects on tax revenue with unchanged behaviour. The behavioural responses constitute new entry of secondary earners (term 4) as well as new entry by primary earners (term 5).

The employment effects of the reform can be expressed using the participation elasticities from the main text. The change in total employment among couples is 


$$
\frac{d E_{1}^{h}}{d \theta}+\frac{d E_{2}^{h}}{d \theta}=\frac{\partial E_{1}^{h}}{\partial \bar{q}_{p}^{h}} \frac{d \bar{q}_{p}^{h}}{d \theta}=-\frac{\partial E_{1}^{h}}{\partial z_{p}^{h}\left(1-a_{p}^{h}\right)} z_{p}^{h} \frac{\partial a_{p}^{h}}{\partial \theta}=-\frac{1}{1-a_{p}^{h}} \frac{\partial a_{p}^{h}}{\partial \theta} \eta_{p}^{h} E_{1}^{h},
$$

where we have used

$$
\frac{\partial a_{p}^{h}}{\partial \theta}=\left(\frac{\partial T_{h}(1,0)}{\partial \theta}-\frac{\partial T_{h}(0,0)}{\partial \theta}\right) / z_{p}^{h}(0)
$$

The change in secondary employment is

$$
\frac{d E_{2}^{h}}{d \theta}=\frac{\partial E_{2}^{h}}{\partial \bar{q}_{s}^{h}} \frac{d \bar{q}_{s}^{h}}{d \theta}=-\frac{\partial E_{2}^{h}}{\partial z_{s}^{h}\left(1-a_{s}^{h}\right)} z_{s}^{h} \frac{\partial a_{s}^{h}}{\partial \theta}=-\frac{1}{1-a_{s}^{h}} \frac{\partial a_{s}^{h}}{\partial \theta} \eta_{s}^{h} E_{2}^{h},
$$

where use is made of

$$
\frac{\partial a_{s}^{h}}{\partial \theta}=\left(\frac{\partial T_{h}(1,1)}{\partial \theta}-\frac{\partial T_{h}(1,0)}{\partial \theta}\right) / z_{s}^{h}
$$

Using (A-4) and (A-6) we can rewrite (A-3) as

$$
\begin{aligned}
\frac{d R}{d \theta}= & \sum_{h}\left[\frac{\partial T_{h}(1,1)}{\partial \theta} E_{2}^{h}+\frac{\partial T_{h}(1,0)}{\partial \theta} E_{1}^{h}+\frac{\partial T_{h}(0,0)}{\partial \theta} E_{0}^{h}\right] \\
& -\sum_{h}\left[\frac{a_{p}^{h}}{1-a_{p}^{h}} \frac{\partial a_{p}^{h}}{\partial \theta} \eta_{p}^{h} z_{p}^{h} E_{1}^{h}+\frac{a_{s}^{h}}{1-a_{s}^{h}} \frac{\partial a_{s}^{h}}{\partial \theta} \eta_{s}^{h} z_{s}^{h} E_{2}^{h}\right] .
\end{aligned}
$$

Reform A. The first reform has

$$
\frac{\partial T_{h}(1,0)}{\partial \theta}=\frac{\partial T_{h}(0,0)}{\partial \theta}=\frac{\partial T(1,0)}{\partial \theta}>0, \frac{\partial T_{h}(1,1)}{\partial \theta}=\frac{\partial T(1,1)}{\partial \theta}<0 \forall h,
$$

where the tax increase to one- and no-earner families is determined endogenously. Because the reform is purely redistributive, government revenue must remain unchanged, $\frac{d R}{d \theta}=0$, implying

$$
-\frac{\partial T(1,0)}{\partial \theta}=\frac{\frac{\partial T(1,1)}{\partial \theta} E_{2}\left(1-\sum_{h} \frac{E_{2}^{h}}{E_{2}} \frac{a_{s}^{h}}{1-a_{s}^{h}} \eta_{s}^{h}\right)}{N-E_{2} \sum_{h} \frac{E_{2}^{h}}{E_{2}}\left(1-\frac{a_{s}^{h}}{1-a_{s}^{h}} \eta_{s}^{h}\right)},
$$

where $E_{2}=\sum_{h} E_{2}^{h}$ is the total number of two-earner households in the economy and where we have used (da/dheta). From the envelope theorem and the marginal nature of the reform, monetary gains and losses are simply the direct changes in tax liabilities. Because all two-earner couples gain and all zero- and one-earner co uples lose, we have 


$$
\Psi_{A}=-\frac{-\sum_{h} \frac{\partial T(1,0)}{\partial \theta}\left(N_{h}-E_{2}^{h}\right)}{-\sum_{h} \frac{\partial T(1,1)}{\partial \theta} E_{2}^{h}}=\frac{-\frac{\partial T(1,0)}{\partial \theta}\left(N-E_{2}\right)}{\frac{\partial T(1,1)}{\partial \theta} E_{2}}=\frac{\left(N-E_{2}\right)\left(1-\sum_{h} \frac{E_{2}^{h}}{E_{2}} \frac{a_{s}^{h}}{1-a_{s}^{h}} \eta_{s}^{h}\right)}{N-E_{2} \sum_{h} \frac{E_{2}^{h}}{E_{2}}\left(1-\frac{a_{s}^{h}}{1-a_{s}^{h}} \eta_{s}^{h}\right)} .
$$

By inserting $e_{2} \equiv E_{2} / N$ and $e_{2}^{h} \equiv E_{2}^{h} / E_{2}$, we obtain expression (6).

Reform B. The second reform implies

$$
\frac{\partial T_{h}(0,0)}{\partial \theta}=0, \frac{\partial T_{h}(1,0)}{\partial \theta}=\frac{\partial T(1,0)}{\partial \theta}>0, \frac{\partial T_{h}(1,1)}{\partial \theta}=\frac{\partial T(1,1)}{\partial \theta}<0 \quad \forall h,
$$

again with the tax increase for two-earner couples exogenously given. We find

$$
-\frac{\partial T(1,0)}{\partial \theta}=\frac{\frac{\partial T(1,1)}{\partial \theta} E_{2}\left(1-\sum_{h} \frac{E_{2}^{h}}{E_{2}} \frac{a_{s}^{h}}{1-a_{s}^{h}} \eta_{s}^{h}\right)}{E_{1}\left(1-\sum_{h} \frac{E_{1}^{h}}{E_{1}} \frac{a_{p}^{h}}{1-a_{p}^{h}} \eta_{p}^{h}\right)+\sum_{h} E_{2}^{h} \frac{a_{s}^{h}}{1-a_{s}^{h}} \eta_{s}^{h}},
$$

where $E_{1}=\sum_{h} E_{1}^{h}$ is the number of one-earner households and where we have used eqs. (A-5) and (A7) as well as the fact that only primary earners in one-earner couples respond to the reform. The trade-off between equity and efficiency equals $\Psi_{B}=-\frac{-\frac{\partial T(1,1)}{\partial \theta} E_{2}}{-\frac{\partial T(1,0)}{\partial \theta} E_{1}}$. By inserting the derivatives from above and the definitions $e_{1} \equiv E_{1} / N, e_{1}^{h}=E_{1}^{h} / E_{1}, e_{2} \equiv E_{2} / N$ and $e_{2}^{h} \equiv E_{2}^{h} / E_{2}$, we obtain expression (7).

\section{APPENDIX B: THE INTENSIVE-EXTENSIVE MODEL}

We introduce intensive responses by allowing individuals to choose working hours subject to the costs of working time given by $v_{p}\left(z_{p} / n_{p}\right)$ for primary earners and $v_{s}\left(z_{s} / n_{s}\right)$ for secondary earners, where $z / n$ is working time for an individual with earnings $z$ and innate ability $n$. The household utility function is now given by

$$
u\left(c, z_{p}, z_{s}\right)=c-n_{p} v_{p}\left(\frac{z_{p}}{n_{p}}\right)-n_{s} v_{s}\left(\frac{z_{s}}{n_{s}}\right)-q_{p} \cdot 1\left(z_{p}>0\right)-q_{s} \cdot 1\left(z_{s}>0\right) .
$$

Conditional on working, the primary earner chooses working hours according to 


$$
1-m_{p}^{h}(l)=v_{p}^{\prime}\left(\frac{z_{p}^{h}(l)}{n_{p}^{h}}\right) \text { for } l=0,1
$$

where $m_{p}^{h}(\cdot) \equiv T_{p}^{\prime}$ is the marginal tax rate faced by the primary earner, which may depend on the work status of the secondary earner. Thus, $l=1$ denotes a working spouse and $l=0$ represents a non-working secondary earner. Similarly, the number of working hours for the secondary earners conditional on participation satisfies

$$
1-m_{s}^{h}=v_{s}^{\prime}\left(\frac{z_{s}^{h}}{n_{s}^{h}}\right)
$$

where $m_{s}^{h} \equiv T_{s}^{\prime}$ denotes the marginal tax rate for the secondary earner (which does not depend on the work status of the primary earner because a working secondary earner is always married to a working primary earner). Household behaviour along the intensive margin is captured by the intensive elasticities

$$
\varepsilon_{p}^{h}(l)=\frac{1-m_{p}^{h}(l)}{z_{p}^{h}(l)} \frac{\partial z_{p}^{h}(l)}{\partial\left[1-m_{p}^{h}(l)\right]} \text { for } l=0,1, \quad \varepsilon_{s}^{h}=\frac{1-m_{s}^{h}}{z_{s}^{h}} \frac{\partial z_{s}^{h}}{\partial\left(1-m_{s}^{h}\right)},
$$

which give the change in earnings in response to a change in the net-of-tax rate rates for the primary and the secondary earner, respectively. Since the marginal tax rates of an individual may now depend on spousal income, so may the choice of earnings. In particular, the earnings of the primary earner are likely to change when the secondary earner enters the labour market. Behaviour along the extensive margin is governed by the exact same logic as in the simpler model: the primary earner in household $h$ enters whenever entry increases the family's utility, i.e., when $V_{h}(1,0)-V(0,0) \geq q_{p}$. Similarly, the secondary earner in household $h$ enters whenever $V_{h}(1,1)-V_{h}(1,0) \geq q_{s} \cdot{ }^{24}$ Compared to the simpler model, the correct definition of the secondary earner participation tax rate now includes the tax implications of the change in primary earnings, i.e., $a_{s}^{h}=T\left(z_{p}^{h}(1), z_{s}^{h}, \theta\right)-T\left(z_{p}^{h}(0), 0, \theta\right) / z_{s}^{h} \cdot{ }^{25}$

The definition of government revenue $R$ is unchanged. The change in $R$ as a result of the reform, $d \theta$, is

24. Assumption (qs) is again sufficient to solve the double screening problem.

25. In the empirical simulations, we are forced to assume that primary earnings remain unchanged when the secondary earner enters. 


$$
\begin{aligned}
\frac{d R}{d \theta}= & \sum_{h}\left[\frac{\partial T_{h}[1,1]}{\partial \theta} E_{2}^{h}+\frac{\partial T_{h}[1,0]}{\partial \theta} E_{1}^{h}+\frac{\partial T_{h}(0,0)}{\partial \theta} E_{0}^{h}\right. \\
& +\left[T_{h}(1,1)-T_{h}(1,0)\right] \frac{d E_{2}^{h}}{d \theta}+\left[T_{h}(1,0)-T_{h}(0,0)\right]\left(\frac{d E_{1}^{h}}{d \theta}+\frac{d E_{2}^{h}}{d \theta}\right) \\
& \left.+m_{p}^{h}(1) \frac{d z_{p}^{h}(1)}{d \theta} E_{2}^{h}+m_{s}^{h} \frac{d z_{s}^{h}}{d \theta} E_{2}^{h}+m_{p}^{h}(0) \frac{d z_{p}^{h}(0)}{d \theta} E_{1}^{h}\right]
\end{aligned}
$$

As before, the employment effects can be rewritten using elasticities to find

$$
\begin{aligned}
\frac{d R}{d \theta}= & \sum_{h}\left[\frac{\partial T_{h}(1,1)}{\partial \theta} E_{2}^{h}+\frac{\partial T_{h}(1,0)}{\partial \theta} E_{1}^{h}+\frac{\partial T_{h}(0,0)}{\partial \theta} E_{0}^{h}\right. \\
& -\frac{a_{p}^{h}}{1-a_{p}^{h}} \frac{\partial a_{p}^{h}}{\partial \theta} \eta_{p}^{h} z_{p}^{h}(0) E_{1}^{h}-\frac{a_{s}^{h}}{1-a_{s}^{h}} \frac{\partial a_{s}^{h}}{\partial \theta} \eta_{s}^{h} z_{s}^{h} E_{2}^{h} \\
& -\frac{m_{p}^{h}(1)}{1-m_{p}^{h}(1)} \frac{\partial m_{p}^{h}(1)}{\partial \theta} \varepsilon_{p}^{h}(1) z_{p}^{h}(1) E_{2}^{h} \\
& -\frac{m_{s}^{h}}{1-m_{s}^{h}} \frac{\partial m_{s}^{h}}{\partial \theta} \varepsilon_{s}^{h} z_{s}^{h} E_{2}^{h} \\
& \left.-\frac{m_{p}^{h}(0)}{1-m_{p}^{h}(0)} \frac{\partial m_{p}^{h}(0)}{\partial \theta} \varepsilon_{p}^{h}(0) z_{p}^{h}(0) E_{1}^{h}\right] .
\end{aligned}
$$

Reform C. The details of the reform are

$$
\begin{aligned}
\frac{\partial m_{p}^{h}(1)}{\partial \theta} & =\frac{\partial T_{h}(0,0)}{\partial \theta}=0, \frac{\partial m_{p}^{h}(0)}{\partial \theta}=\tau \Rightarrow \frac{\partial T_{h}(1,0)}{\partial \theta}=\tau z_{p}^{h}(0), \\
\frac{\partial m_{s}^{h}}{\partial \theta} & =-t \Rightarrow \frac{\partial T_{h}(1,1)}{\partial \theta}=-t z_{s}^{h} \forall h,
\end{aligned}
$$

where $t>0$ is exogenous while $\tau$ is endogenously determined by government budget neutrality, $d R=0$. This implies

$$
\tau=\frac{t \sum_{h} z_{s}^{h} E_{2}^{h}\left(1-\frac{a_{s}^{h}}{1-a_{s}^{h}} \eta_{s}^{h}-\frac{m_{s}^{h}}{1-m_{s}^{h}} \varepsilon_{s}^{h}\right)}{\sum_{h} z_{p}^{h}(0) E_{1}^{h}\left(1-\frac{a_{p}^{h}}{1-a_{p}^{h}} \eta_{p}^{h}+\frac{E_{2}^{h}}{E_{1}^{h}} \frac{a_{s}^{h}}{1-a_{s}^{h}} \eta_{s}^{h}-\frac{m_{p}^{h}(0)}{1-m_{p}^{h}(0)} \varepsilon_{p}^{h}(0)\right)} .
$$

Using this expression, the trade-off between equity and efficiency becomes 


$$
\begin{aligned}
\Psi_{C} & =-\frac{-\sum_{h} \frac{\partial T_{h}(1,0)}{\partial \theta} E_{p}^{h}}{-\sum_{h} \frac{\partial T_{h}(1,1)}{\partial \theta} E_{s}^{h}}=\frac{\tau \sum_{h} z_{p}^{h}(0) E_{1}^{h}}{t \sum_{h} z_{s}^{h} E_{2}^{h}} \\
& =\frac{1-\sum_{h} s_{s}^{h}\left(\frac{a_{s}^{h}}{1-a_{s}^{h}} \eta_{s}^{h}+\frac{m_{s}^{h}}{1-m_{s}^{h}} \varepsilon_{s}^{h}\right)}{1-\sum_{h} s_{p}^{h}\left(\frac{a_{p}^{h}}{1-a_{p}^{h}} \eta_{p}^{h}-\frac{e_{2}^{h} e_{2}}{e_{1}^{h} e_{1}} \frac{a_{s}^{h}}{1-a_{s}^{h}} \eta_{s}^{h}+\frac{m_{p}^{h}(0)}{1-m_{p}^{h}(0)} \varepsilon_{p}^{h}(0)\right)},
\end{aligned}
$$

where $s_{p}^{h} \equiv z_{p}^{h}(0) E_{p}^{h} /\left(\sum_{h} z_{p}^{h}(0) E_{p}^{h}\right)$ is the share of all earnings in one-earner families that accrues to households of type $h$, and $s_{s}^{h} \equiv z_{s}^{h} E_{s}^{h} / \sum_{h} z_{s}^{h} E_{s}^{h}$ is the share of all secondary earnings accruing to household $h$. 


\section{REFERENCES}

Alesina, A. and A. Ichino (2007). Gender based taxation. Harvard University Working Paper, April 2007.

Alm, J. and L. Whittington (1995a). Income Taxes and the Marriage Decision. Applied Economics 27, 2531.

Alm, J. and L. Whittington (1995b), Does the Income Tax Affect Marital Decisions? National Tax Journal 48, 565-72.

Alm, J. and L.A. Whittington (1996). The Rise and Fall and Rise...of the Marriage Tax. National Tax Journal, 49, 571-89.

Alm, J. and L.A. Whittington (1997). Til Death or Taxes Do Us Part: The Effect of Income Taxation on Divorce. Journal of Human Resources 32, 388-412.

Alm, J. and L.A. Whittington (1999). For Love or Money? The Impact of Income Taxes on Marriage. Economica, 66, 571-89.

Alm, J., S. Dickert-Conlin and L.A. Whittington (1999). Policy Watch: The Marriage Penalty. Journal of Economic Perspectives, 13, 193-204.

Armstrong, M. and J.-C. Rochet (1999). Multi-dimensional screening: A user's guide. European Economic Review, 43, 959-79.

Bitler, M., J. Gelbach, H.W. Hoynes, and M. Zavodny (2004). The Impact of Welfare Reform on Marriage and Divorce. Demography 41, 213-236.

Blundell, R.W. (1995). The Impact of Taxation on Labour Force Participation and Labour Supply, in OECD Job Study: Taxation, Employment, and Unemployment, Chapter 3, OECD: Paris.

Blundell, R.W. and T. MaCurdy (1999). Labour Supply: A Review of Alternative Approaches. In O. Ashenfelter and D. Card (eds.), Handbook of Labour Economics, Vol. 3A, Amsterdam: Elsevier Science B.V., 1559-1695.

Boskin, M. J.and E. Sheshinski (1983). Optimal tax treatment of the family: Married couples. Journal of Public Economics, 20, 281-97.

Brett, C. (2006). Optimal Nonlinear Taxes for Families. International Tax and Public Finance 14, 225261.

Browning, E.K. and W.R. Johnson (1984). The Trade-Off between Equality and Efficiency. Journal of Political Economy 92, 175-203 
Bull, N., J. Holtzblatt and J.R. Nunns (1999). Defining and Measuring Marriage Penalties and Bonuses. OTA Paper 82.

Cremer, Helmuth, Jean-Marie Lozachmeur, and Pierre Pestieau (2007). Income Taxation of Couples and the Tax Unit Choice. Working Paper, 2007.

Dickert-Conlin, S. (1999). Taxes and Transfers: Their Effect on the Decision to End a Marriage. Journal of Public Economics 73, 217-40.

Dickert-Conlin, S. and S. Houser (1998). Taxes and Transfers: A New Look at the Marriage Penalty. National Tax Journal 51, 175-217.

Eissa, N. (1995). Taxation and Labour Supply of Married Women: The Tax Reform Act of 1986 as a Natural Experiment. NBER Working Paper No. 5023.

Eissa, N. and H.W. Hoynes (2000a). Explaining the Fall and Rise in the Tax Cost of Marriage: The Effect of Tax Laws and Demographic Trends, 1984-1997. National Tax Journal 53, 683-711.

Eissa, N. and H.W. Hoynes (2000b). Tax and Transfer Policy, and Family Formation: Marriage and Cohabitation. Working Paper, December 2000.

Eissa. N. and H.W. Hoynes (2004). Taxes and the Labour Market Participation of Married Couples: The Earned Income Tax Credit. Journal of Public Economics 88, 1931-1958.

Eissa, N., H.J. Kleven, and Kreiner, C.T. Evaluation of Four Tax Reforms in the United States: Labor Supply and Welfare Effects for Single Mothers Journal of Public Economics 92, 2008, 795-816.

Feenberg, D. and H.S. Rosen (1995). Recent Developments in the Marriage Tax. National Tax Journal 48, 91-101.

Heckman, J. (1993). What Has Been Learned About Labor Supply in the Past Twenty Years?, American Economic Review Papers and Proceedings, 83, 116-21.

Hoynes, H.W. (1997a). Does Welfare Play Any Role in Female Headship Decisions? Journal of Public Economics 65, 89-117.

Hoynes, H.W. (1997b). Work, Welfare, and Family Structure: What Have We Learned?, in Fiscal Policy: Lessons From Economic Research, Alan Auerbach (ed.), MIT Press: Cambridge, Massachusetts.

Immervoll, H. (2004). Average and marginal effective tax rates facing workers in the EU. A micro-level analyis of levels, distributions and driving factors. OECD Social, Employment and Migration Working Paper No. 19, OECD: Paris.

Immervoll, H. and C. O'Donoghue (2003). Employment transitions in 13 European countries. Levels, distributions and determining Factors of net replacement rates. CESifo Working Paper No. 1091, CESifo: Munich.

Immervoll H., H.J Kleven, C.T. Kreiner and E. Saez (2007). Welfare Reform in European Countries: A Microsimulation Analysis. Economic Journal, 117, 1-44.

Kleven, H.J and C.T. Kreiner (2006). The Efficient Taxation of Couples. Mimeo. 
Kleven, H.J., C.T. Kreiner and E. Saez (2007). The Optimal Income Taxation of Couples as a MultiDimensional Screening Problem. CESifo Working Paper 2092, September 2007.

Kleven, H.J., C.T. Kreiner and E. Saez (2008). The Optimal Income Taxation of Couples. Working Paper, August 2008. Forthcoming in Econometrica.

Mirrlees, J.A. (1976). Optimal tax theory: a synthesis. Journal of Public Economics 6, 327-358.

Mirrlees, James A. (1986). The Theory of Optimal Taxation, in K.J. Arrow and M.D. Intrilligator (eds.), Handbook of Mathematical Economics vol. 3. Elsevier Science B.V.: Amsterdam.

Moffitt, R. (1998). The Effect of Welfare on Marriage and the Family, in Robert Moffitt (ed.), Welfare and Family and Reproductive Behavior, National Academy Press: Washington D.C.

OECD (2002). Revenue Statistics: 1965-2001. Paris: OECD.

OECD (2003). National Accounts, Volume II 1990-2001. Paris: OECD.

Pechman, J.A. (1987). Federal Tax Policy. Brookings Institution: Washington D.C.

Pechman, J. and G. Engelhardt (1990). The Income Tax Treatment of the Family: An International Perspective. National Tax Journal 43, 1-22.

Rosen, H.S. (1977). Is it time to abandon joint filing? National Tax Journal, 30, 423-8.

Rosen, H.S. (1987). The Marriage Tax Is Down But Not Out. National Tax Journal 40, 567-75.

Rubenfeld, J. (1997). Affirmative Action. Yale Law Journal 107, 427-472.

Saez E. (2002). Optimal Income Transfer Programs: Intensive versus Extensive Labor Supply Responses. Quarterly Journal of Economics, 117, 1039-73.

Schroyen, Fred (2003). Redistributive taxation and the household: the case of individual filings. Journal of Public Economics 87, 2527-2547.

Sutherland H. (2001). Final Report EUROMOD: An Integrated European Benefit-Tax Model. EUROMOD Working Paper No. EM9/01. 
Table 1. Share of women among secondary earners

\begin{tabular}{|c|c|c|c|}
\hline Country & $\begin{array}{c}\text { One-earner } \\
\text { couples }\end{array}$ & $\begin{array}{c}\text { Two-earner } \\
\text { couples }\end{array}$ & $\begin{array}{l}\text { One- and two- } \\
\text { earner couples }\end{array}$ \\
\hline Austria & 0.96 & 0.87 & 0.90 \\
\hline Belgium & 0.92 & 0.73 & 0.78 \\
\hline Denmark & 0.83 & 0.82 & 0.82 \\
\hline Finland & 0.65 & 0.76 & 0.75 \\
\hline France & 0.93 & 0.74 & 0.80 \\
\hline Germany & 0.91 & 0.78 & 0.83 \\
\hline Greece & 0.98 & 0.75 & 0.90 \\
\hline Ireland & 0.96 & 0.78 & 0.89 \\
\hline Italy & 0.94 & 0.81 & 0.88 \\
\hline Luxembourg & 0.99 & 0.77 & 0.89 \\
\hline Netherlands & 0.95 & 0.88 & 0.91 \\
\hline Portugal & 0.95 & 0.78 & 0.85 \\
\hline Spain & 0.97 & 0.73 & 0.89 \\
\hline Sweden & 0.66 & 0.76 & 0.75 \\
\hline United Kingdom & 0.78 & 0.83 & 0.81 \\
\hline
\end{tabular}

Note: Secondary earners are defined as the spouses with the lowest earnings in the couples.

Source: EUROMOD Microsimulation Model. 
Table 2. Participation tax rates and labour market outcomes

\begin{tabular}{|c|c|c|c|c|c|}
\hline Country & $\begin{array}{l}\text { Participation Tax } \\
\text { Primary Earners }\end{array}$ & $\begin{array}{c}\text { Participation Tax } \\
\text { Secondary Earners }\end{array}$ & $\begin{array}{c}\text { Relative Tax } \\
\text { (PE / SE) }\end{array}$ & $\begin{array}{c}\text { Relative Participation } \\
\text { (PE / SE ) }\end{array}$ & $\begin{array}{c}\text { Relative Earnings } \\
\text { ( PE / SE ) }\end{array}$ \\
\hline Austria & 0.63 & 0.36 & 1.72 & 1.66 & 2.18 \\
\hline Belgium & 0.73 & 0.74 & 0.98 & 1.38 & 1.95 \\
\hline Denmark & 0.73 & 0.53 & 1.38 & 1.13 & 1.74 \\
\hline Finland & 0.60 & 0.36 & 1.65 & 1.05 & 1.66 \\
\hline France & 0.85 & 0.63 & 1.35 & 1.53 & 1.67 \\
\hline Germany & 0.63 & 0.51 & 1.22 & 1.53 & 1.99 \\
\hline Greece & 0.27 & 0.28 & 0.97 & 3.13 & 1.61 \\
\hline Ireland & 0.54 & 0.44 & 1.22 & 2.55 & 2.18 \\
\hline Italy & 0.35 & 0.46 & 0.77 & 2.15 & 1.51 \\
\hline Luxembourg & 0.50 & 0.32 & 1.54 & 2.52 & 2.25 \\
\hline Netherlands & 0.56 & 0.44 & 1.28 & 1.68 & 2.61 \\
\hline Portugal & 0.37 & 0.41 & 0.90 & 1.74 & 1.56 \\
\hline Spain & 0.34 & 0.41 & 0.83 & 3.25 & 1.61 \\
\hline Sweden & 0.66 & 0.51 & 1.28 & 1.07 & 1.53 \\
\hline United Kingdom & 0.56 & 0.20 & 2.79 & 1.47 & 2.20 \\
\hline
\end{tabular}

Note: The first two columns list the average effective participation tax rates for primary earners in one-earner couples and secondary earners in two-earner families, respectively. Columns 4 shows relative participation rates of primary and secondary earners and column 5 lists the relative average earnings of primary and secondary earners conditional on working. The calculation of the tax rates is described in the text.

Source: EUROMOD Microsimulation Model. 
Table 3. Inter-household utility trade-off for reforms A and B

\begin{tabular}{|c|c|c|c|c|c|c|c|c|}
\hline \multirow[b]{4}{*}{ Country } & \multicolumn{6}{|c|}{ Constant Elasticity } & \multirow{2}{*}{\multicolumn{2}{|c|}{$\begin{array}{c}\text { Elasticity Profile } \\
\text { Scenario } 4\end{array}$}} \\
\hline & \multicolumn{2}{|c|}{ Scenario 1} & \multicolumn{2}{|c|}{ Scenario 2} & \multicolumn{2}{|c|}{ Scenario 3} & & \\
\hline & $\eta_{p}=0.1$ & $\eta_{s}=0.5$ & $\eta_{p}=0.1$ & $\eta_{\mathrm{s}}=0.7$ & $\eta_{p}=0.3$ & $\eta_{s}=0.3$ & $\eta_{p}=0.1$ & $\eta_{\mathrm{s}}=0.5$ \\
\hline & $A$ & B & $A$ & B & $A$ & B & A & B \\
\hline Austria & 0.32 & 0.48 & 0.18 & 0.26 & 0.51 & No Gainers & 0.38 & 0.67 \\
\hline Belgium & \multicolumn{2}{|c|}{ No Losers } & \multicolumn{2}{|c|}{ No Losers } & \multicolumn{2}{|c|}{ No Losers } & \multicolumn{2}{|c|}{ No Losers } \\
\hline Denmark & 0.01 & 0.01 & \multicolumn{2}{|c|}{ No Losers } & 0.12 & No Gainers & 0.01 & 0.02 \\
\hline Finland & 0.13 & 0.07 & 0.05 & 0.02 & 0.26 & No Gainers & 0.18 & 0.10 \\
\hline France & \multicolumn{2}{|c|}{ No Losers } & \multicolumn{2}{|c|}{ No Losers } & 0.16 & No Gainers & \multicolumn{2}{|c|}{ No Losers } \\
\hline Germany & 0.14 & 0.16 & \multicolumn{2}{|c|}{ No Losers } & 0.35 & No Gainers & 0.21 & 0.27 \\
\hline Greece & 0.61 & 0.65 & 0.48 & 0.50 & 0.76 & 0.99 & 0.60 & 0.63 \\
\hline I reland & 0.27 & 0.31 & 0.06 & 0.07 & 0.52 & 1.73 & 0.30 & 0.39 \\
\hline Italy & 0.33 & 0.32 & 0.14 & 0.13 & 0.55 & 0.80 & 0.34 & 0.34 \\
\hline Luxembourg & 0.43 & 0.53 & 0.27 & 0.32 & 0.62 & 1.66 & 0.54 & 0.69 \\
\hline Netherlands & 0.25 & 0.31 & 0.11 & 0.12 & 0.46 & 3.21 & 0.28 & 0.37 \\
\hline Portugal & 0.28 & 0.29 & 0.12 & 0.12 & 0.50 & 0.85 & 0.38 & 0.39 \\
\hline Spain & 0.46 & 0.48 & 0.28 & 0.29 & 0.66 & 0.89 & 0.45 & 0.47 \\
\hline Sweden & 0.07 & 0.03 & \multicolumn{2}{|c|}{ No Losers } & 0.20 & No Gainers & 0.07 & 0.04 \\
\hline United Kingdom & 0.58 & 0.77 & 0.46 & 0.56 & 0.72 & No Gainers & 0.65 & 1.03 \\
\hline
\end{tabular}

Note: The trade-off is calculated using formula (6) in the text for reform A and formula (7) for reform B. $\eta_{p}$ is the participation elasticity of primary earners $(P E)$ and $\eta_{s}$ is the participation elasticity of secondary earners (SE). Note that the primary earner elasticity does not affect the trade-off in reform $A$. In scenarios 1-3, the elasticities are the same for all income groups. In scenario 4, earnings responses are concentrated at the lower end of the income distribution. Specifically, $\eta_{p}$ is 0.3 for primary earners in the lowest quintile of the PE earnings distribution (PEq1), 0.1 for PEq2 and PEq3, and 0 for PEq4 and PEq5. For secondary earners, the elasticity scenario is 1 for the lowest quintile of the SE earnings distribution (SEq1), 0.8 for SEq2, 0.5 for SEq3, 0.2 for SEq4 and 0 for SEq5. The average elasticities are listed above the results.

Source: Authors' own calculations based on the EUROMOD microsimulation model. 
Table 4. Inter-household utility trade-off for reform C

\begin{tabular}{|c|c|c|c|}
\hline \multirow[b]{4}{*}{ Country } & \multicolumn{3}{|c|}{ Constant Elasticity } \\
\hline & \multirow[t]{3}{*}{ Scenario 1} & Scenario 2 & \multirow[t]{2}{*}{ Scenario 3} \\
\hline & & $\eta_{p}=0.1$ & \\
\hline & & $\varepsilon_{\mathrm{p}}=\varepsilon_{\mathrm{s}}=0.1$ & $\varepsilon_{\mathrm{p}}=0 \quad \varepsilon_{\mathrm{s}}=0.2$ \\
\hline Austria & 0.42 & 0.34 & 0.18 \\
\hline Belgium & No Losers & No Losers & No Losers \\
\hline Denmark & 0.01 & No Losers & No Losers \\
\hline Finland & 0.05 & 0.03 & 0.00 \\
\hline France & No Losers & No Losers & No Losers \\
\hline Germany & 0.11 & 0.00 & No Losers \\
\hline Greece & 0.66 & 0.63 & 0.51 \\
\hline Ireland & 0.26 & 0.15 & 0.01 \\
\hline Italy & 0.30 & 0.23 & 0.11 \\
\hline Luxembourg & 0.44 & 0.34 & 0.17 \\
\hline Netherlands & 0.29 & 0.21 & 0.09 \\
\hline Portugal & 0.18 & 0.11 & 0.03 \\
\hline Spain & 0.48 & 0.45 & 0.35 \\
\hline Sweden & 0.03 & 0.01 & No Losers \\
\hline United Kingdom & 0.66 & 0.65 & 0.51 \\
\hline
\end{tabular}

Note: The trade-off is calculated using formula (A-9) in Appendix D. $\eta p$ is the participation elasticity of primary earners (PE) and $\eta_{s}$ is the participation elasticity of secondary earners (SE). Similarly, $\varepsilon_{\mathrm{p}}$ is the intensive elasticity of the PE and $\varepsilon_{\mathrm{s}}$ is the intensive elasticity of the SE. The participation elasticities are set at 0.1 for $\eta_{p}$ and 0.5 for $\eta_{s}$ in all scenarios. The elasticities never vary with income groups.

Source: Authors' own calculations based on the EUROMOD microsimulation model. 
Table 5. Annual marriage penalties in 2007 euros for families with two children, 1998

\begin{tabular}{|c|c|c|c|c|c|c|c|c|c|c|c|c|c|c|c|}
\hline Family Income Percentiles & AT & BE & DK & $\mathbf{F I}$ & FR & GE & GR & IR & IT & LU & NL & PT & SP & sw & UK \\
\hline PE 0 - SE 0 & 5141 & 9770 & 7077 & 3676 & 14472 & 2387 & 1608 & 2224 & 0 & 7433 & 13549 & 0 & 0 & 10187 & 4696 \\
\hline PEp10 - SE 0 & 9353 & 10090 & 11640 & 6668 & 13059 & 5138 & 619 & 9156 & -3234 & 12474 & 13375 & 2276 & 69 & 10495 & 7586 \\
\hline PEp10 - SEp10 & 7167 & 9712 & 11153 & 5116 & 7343 & 6573 & 762 & 10711 & -1025 & 10624 & 11762 & 1125 & 837 & 5987 & 7782 \\
\hline PEp50 - SE 0 & 9353 & 6933 & 18148 & 12114 & 12096 & 9040 & 518 & 9999 & -2307 & 10288 & 13632 & 2151 & 7 & 17444 & 13234 \\
\hline PEp50 - SEp10 & 7178 & 7071 & 11858 & 5611 & 6433 & 7692 & 615 & 7831 & -686 & 4672 & 12343 & 593 & 849 & 5730 & 9406 \\
\hline PEp50 - SE p50 & 496 & -575 & 9411 & 1055 & 2404 & 2267 & 57 & 3561 & 256 & -3169 & 8814 & 355 & 1669 & 752 & 6066 \\
\hline PEp90 - SE 0 & 9353 & 6101 & 21936 & 14040 & 7308 & 8173 & 588 & 14318 & -935 & 3249 & 12195 & -187 & 7 & 17987 & 20780 \\
\hline PEp90 - SEp10 & 7294 & 6110 & 13457 & 7691 & 1962 & 7182 & 686 & 13868 & -158 & -2967 & 10713 & -1621 & 1809 & 5730 & 17130 \\
\hline PEp90 - SEp50 & 496 & -1274 & 10060 & 1055 & -1192 & 3027 & 73 & 7023 & 294 & -8042 & 6663 & -1156 & 2821 & 1938 & 13790 \\
\hline PEp90 - SEp90 & 697 & -575 & 6259 & 737 & -288 & 955 & 244 & 5839 & -422 & -1027 & 7942 & 651 & 3316 & 0 & 2108 \\
\hline
\end{tabular}

Note: The table shows marriage penalties on an annual basis for hypothetical families in 2007 Euros. The calculations are done for different earnings levels for the primary and secondary earner and the earnings levels refer to percentiles in the earnings distribution for primary and secondary earners, respectively. The marriage penalty is calculated as the change in a couple's combined (net-)tax liability upon separation. It is assumed that all individuals occupy rental housing. Following separation, each spouse is assumed to bear rental costs amounting to $50 \%$ of the costs in the married scenario. Further, each spouse retains custody of one child. 1998 figures are converted to 2007 euros using national indices of compensation per employee. Exchange rates are, respectively, the irrevocable euro exchange rates (12 euro countries) and 2007 average annual exchange rates (non-euro countries: Denmark, Sweden, UK).

Sources: EUROMOD microsimulation model, OECD Economic Outlook 82, and Danmarks Nationalbank. 


\section{Figure 1. Participation tax rates of secondary earners for couples with two children}

In percent, at selected earnings levels as a function of primary earnings (vingtiles)

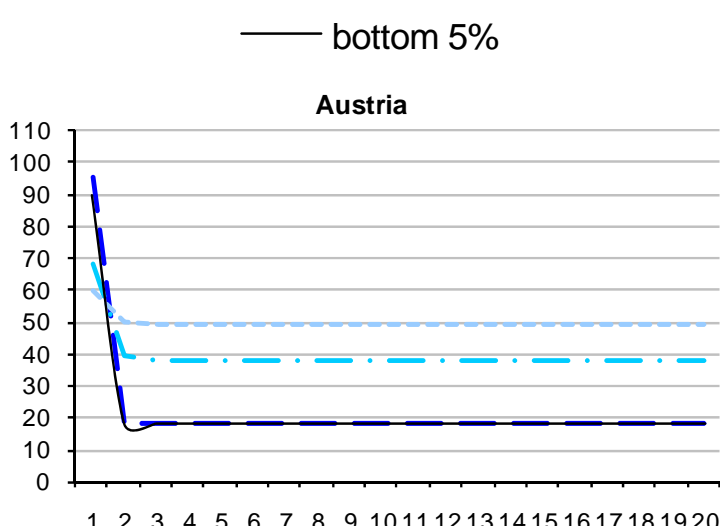

Finland

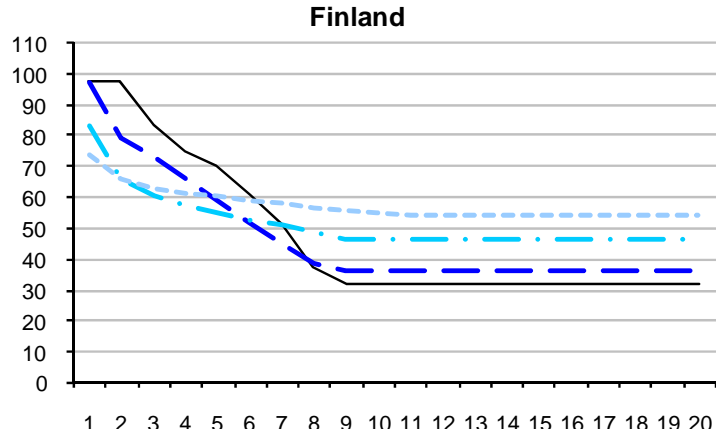

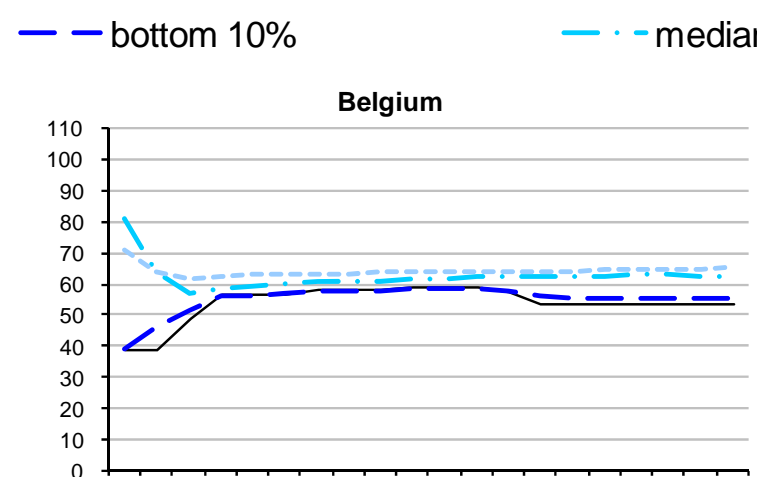

$1 \quad 2 \quad 3 \quad 4 \quad 5 \quad 6 \quad 7 \quad 8 \quad 91011121314151617181920$

France

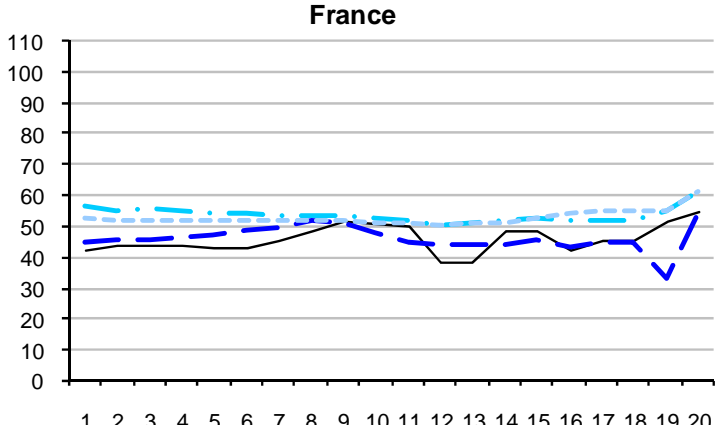

$122 \quad 3 \quad 4 \quad 5 \quad 6 \quad 7 \quad 8 \quad 91011121314151617181920$
- - - top $10 \%$

Denmark

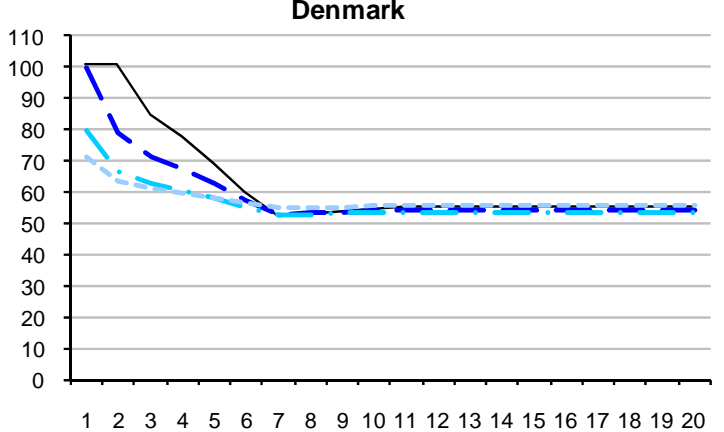

Germany

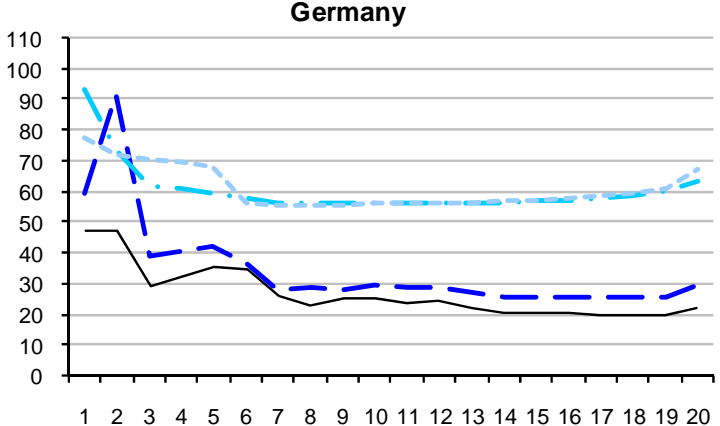

Figure continues on next page 
Figure 1. (cont.)
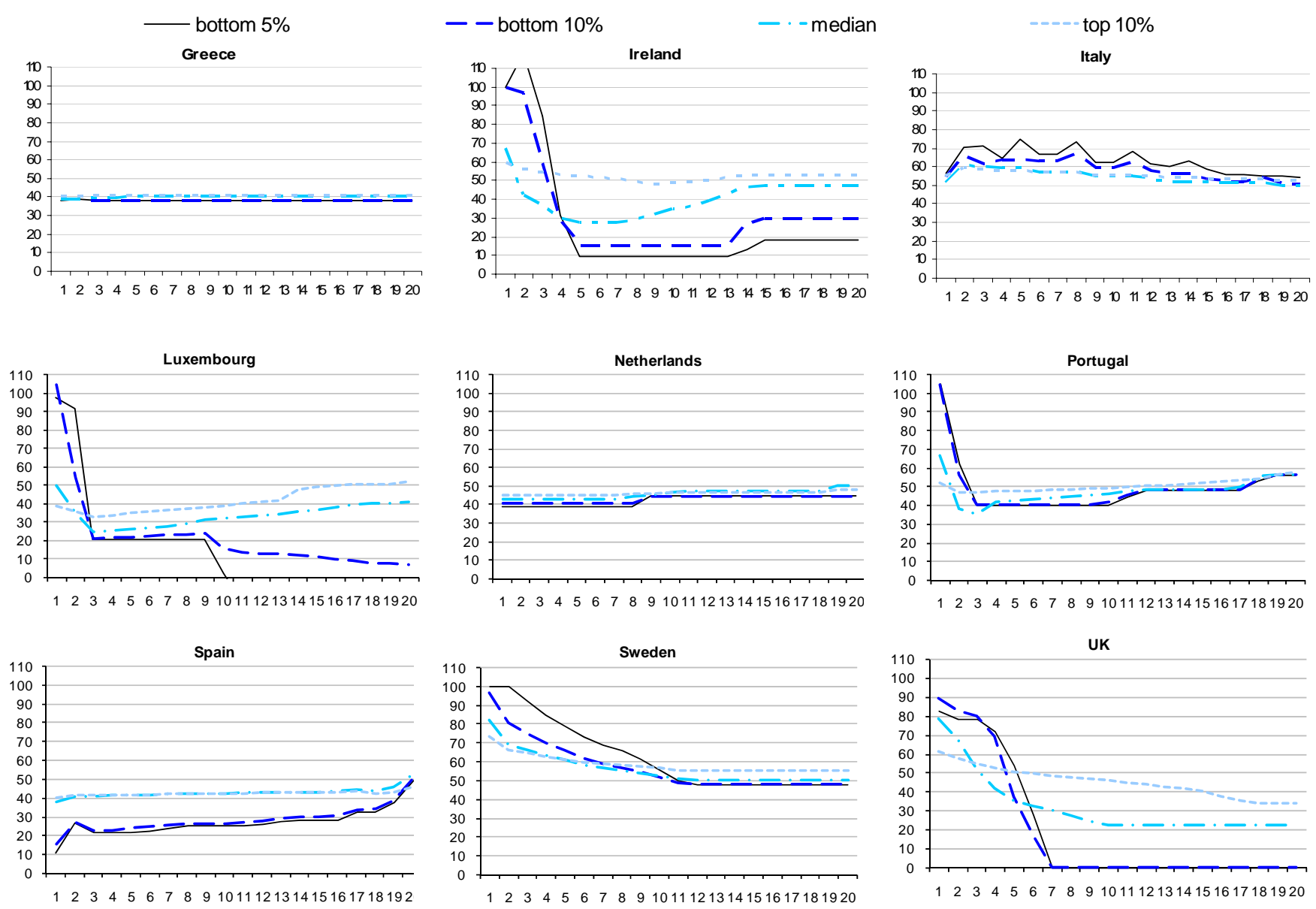

Note: Each figure shows the participation tax rate of the secondary earner (SE) in percent as a function of the earnings of the primary earner (PE), depicted by vingtile group in the PE earnings distribution. The graphs are shown for four different SE earnings levels: the lowest vingtile (SEp5), the lowest decile (SEp10), the median(SEp50), and the top decile (SEp90) of the SE earnings distribution. Source: EUROMOD microsimulation model. 
Figure 2. The double-deviation problem

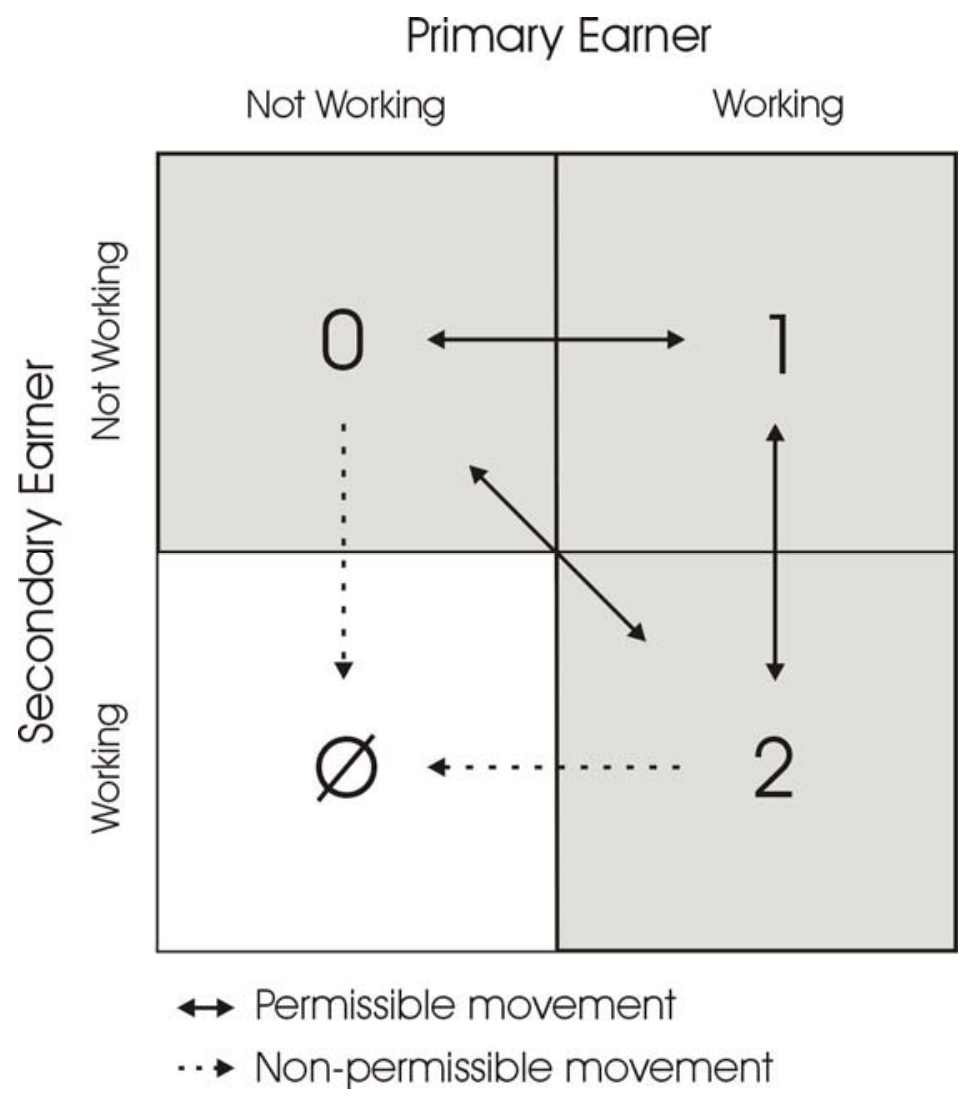


Table A1. Summary of taxes on workers

\begin{tabular}{|c|c|c|c|c|c|c|c|c|c|c|c|c|c|c|c|}
\hline & \multicolumn{5}{|c|}{ Income $\operatorname{Tax}^{7}$} & \multicolumn{4}{|c|}{ SSC (employee) } & \multicolumn{4}{|c|}{ SSC (employer) and Payroll Tax } & \multirow[b]{2}{*}{ features reducing METR and PTR } & \multirow[b]{2}{*}{ features increasing METR and PTR } \\
\hline & $\begin{array}{l}\text { lowesthighest } \\
\text { tax band limitit }\end{array}$ & $\begin{array}{l}\text { lowesthighest } \\
\text { rate }[\%]\end{array}$ & main tax credit ${ }^{2}$ & tax unit & family-related tax provisions & $\begin{array}{l}\text { thres- } \\
\text { hold }^{1}\end{array}$ & rate [\%] & ceiling ${ }^{1}$ & $\begin{array}{l}\operatorname{tax} \\
\text { deductible }\end{array}$ & $\begin{array}{l}\text { thres- } \\
\text { hold }^{1}\end{array}$ & rate [\%] & ceiling ${ }^{1}$ & taxable & & \\
\hline Austria & $17 / 231$ & $\begin{array}{l}21 / 50 \\
4 \text { rates }\end{array}$ & 5 & individual & $\begin{array}{c}\text { deduction for single earners: } \\
\text { tax credits for lone parents }\end{array}$ & 15 & 18.8 & 193 & yes & 15 & $\begin{array}{l}21.3 \\
4.5\end{array}$ & 193 & no & & $\begin{array}{l}\text { 2nd earner: phase-out of single-earner } \\
\text { credit }\end{array}$ \\
\hline Belgium & $24 / 318$ & $\begin{array}{l}25 / 55 \\
7 \text { rates }\end{array}$ & - & individual & $\begin{array}{c}\text { parts of taxable income } \\
\text { transferrable to spouse; } \\
\text { additional tfa for children } \\
\text { and lone parents }\end{array}$ & - & 11.9 & - & yes & - & 45.4 & - & no & & $\begin{array}{l}\text { 2nd earner: phase-out of amount } \\
\text { transferrable from higher-earning } \\
\text { spouse }\end{array}$ \\
\hline Denmark & $12 / 100$ & $\begin{array}{l}40 / 59^{4} \\
3 \text { rates }\end{array}$ & - & individual & $\begin{array}{l}\text { unused deductions } \\
\text { transferrable to spouse }\end{array}$ & - & $\begin{array}{l}9 \\
+ \text { flat amount } \\
\end{array}$ & - & yes & - & $\begin{array}{l}2 \\
+ \text { flat amount }\end{array}$ & - & no & & \\
\hline Finland & $35 / 223$ & $\begin{array}{l}24 / 56^{4} \\
6 \text { rates }\end{array}$ & $\cdot$ & individual & & 58 & $\begin{array}{l}7.6 \\
0.5\end{array}$ & - & yes & - & 24.5 & - & no & $\begin{array}{l}\text { earned income tax allowance (20\% of } \\
\text { earnings above } 11)\end{array}$ & $\begin{array}{c}\text { phase-out of earned income tax and } \\
\text { basic allowanness (startiting at earnings } \\
>31 \text { and } 76 \text { respectively) }\end{array}$ \\
\hline France & $30 / 336$ & $\begin{array}{l}11 / 54 \\
6 \text { rates }\end{array}$ & - & family & & 136 & $\begin{array}{l}0.9 \\
9.6 \\
2.8^{4} \\
3.6 \\
7.6\end{array}$ & $\begin{array}{l}136 \\
409 \\
545\end{array}$ & $\begin{array}{l}\text { yes } \\
\text { yes } \\
\text { yes } \\
\text { yes } \\
\text { partly }\end{array}$ & $\begin{array}{c}- \\
- \\
136\end{array}$ & $\begin{array}{l}19.8 \\
13.4 \\
4.1 \\
5.3\end{array}$ & $\begin{array}{l}136 \\
409 \\
545\end{array}$ & no & $\begin{array}{l}\text { reduced employer contributions rates } \\
\text { for wages }<130 \% \mathrm{MW} \text {. }\end{array}$ & \\
\hline Germany & $\begin{array}{l}30 \\
133 \\
252\end{array}$ & $\begin{array}{l}27.3 \\
37.2 \\
55.7^{5}\end{array}$ & - & $\begin{array}{c}\text { married } \\
\text { couple } \\
\text { (individual } \\
\text { optional) }\end{array}$ & choice of tfa or child benefit & 15 & $\begin{array}{l}7.7 \\
13.4\end{array}$ & $\begin{array}{l}156 \\
208\end{array}$ & yes & 15 & $\begin{array}{l}7.7 \\
13.4\end{array}$ & $\begin{array}{l}156 \\
208\end{array}$ & no & & \\
\hline Greece & $56 / 478$ & $\begin{array}{l}5 / 45 \\
5 \text { rates }\end{array}$ & $\begin{array}{l}\text { max. } 15 \% \text { of } \\
\text { accepted hshld. } \\
\text { expenditure }\end{array}$ & individual & $\begin{array}{l}0.9-1.8 \text { non-refundable tax } \\
\text { credit per child }\end{array}$ & - & 15.9 & $\begin{array}{l}200 ; \\
\text { none for } \\
\text { new jobs }\end{array}$ & yes & - & 28.2 & $\begin{array}{l}\text { 200; } \\
\text { none for } \\
\text { new jobs }\end{array}$ & no & & \\
\hline Ireland & $25 / 80$ & $\begin{array}{l}24 / 46 \\
2 \text { rates }\end{array}$ & - & $\begin{array}{l}\text { married } \\
\text { couple } \\
\text { (individual } \\
\text { optional) }\end{array}$ & - & $\begin{array}{l}41 \\
86\end{array}$ & $\begin{array}{l}4.5 \\
2.3\end{array}$ & 193 & no & 112 & $\begin{array}{l}8.5 \\
12.0 \\
4.0\end{array}$ & $\begin{array}{l}12 \\
231 \\
231\end{array}$ & no & $\begin{array}{l}\text { no tax if income below } 33 \text { (higher limit } \\
\text { if children) }\end{array}$ & $\begin{array}{l}\text { tax-free status phased out above the } \\
33 \text { limit. }\end{array}$ \\
\hline Italy & $0 / 118$ & $\begin{array}{l}19 / 46 \\
5 \text { rates }\end{array}$ & up to 6 & individual & $\begin{array}{l}\text { up to } 2 \text { tax credit for each } \\
\text { dependent family member }\end{array}$ & 56 & $\begin{array}{c}9.0^{4} \\
1\end{array}$ & - & yes & - & $33.0^{4}$ & - & no & & $\begin{array}{l}\text { phase-out of main tax crediti } \\
\text { 2nd earner: phase-out of tax credit tor } \\
\text { dependent spouse; }\end{array}$ \\
\hline Luxembourg & $25 / 250$ & $\begin{array}{l}6 / 47 \\
17 \text { rates }\end{array}$ & & $\begin{array}{l}\text { married } \\
\text { couple }\end{array}$ & $\begin{array}{l}\text { deductions for lone parents } \\
\text { and care expenditure; } 3 \text { tax } \\
\text { creditit per child }\end{array}$ & - & 13.1 & 259 & yes & - & $14.6^{4}$ & 259 & no & $\begin{array}{c}\text { 2nd earner: additional tax deduction if } \\
\text { both spouses work }\end{array}$ & \\
\hline Netherlands & $20 / 212$ & $\begin{array}{l}36^{8} / 60 \\
3 \text { rates }\end{array}$ & - & individual & $\begin{array}{l}\text { additional tfa for lone } \\
\text { parents }\end{array}$ & 54 & $\begin{array}{l}5.3 \\
1.7\end{array}$ & $\begin{array}{l}156 \\
105\end{array}$ & $\begin{array}{l}\text { yes } \\
\text { no }\end{array}$ & 54 & $\begin{array}{l}6.4 \\
5.6 \\
7.9^{4}\end{array}$ & $\begin{array}{l}156 \\
105 \\
156\end{array}$ & $\begin{array}{c}\text { no } \\
\text { yes } \\
\text { no }\end{array}$ & & \\
\hline Portugal & 0/490 & $\begin{array}{l}5^{9} / 40 \\
5 \text { rates }\end{array}$ & 3 & $\begin{array}{l}\text { married } \\
\text { couple }\end{array}$ & $\begin{array}{l}\text { additional } 1.5 \text { tax credit per } \\
\text { child }\end{array}$ & $\cdot$ & 11 & - & no & - & 23.8 & $\cdot$ & no & & \\
\hline Spain & $22 / 492$ & $\begin{array}{l}20 / 56 \\
8 \text { rates }\end{array}$ & 3 & $\begin{array}{l}\text { family } \\
\text { (individual } \\
\text { optional) }\end{array}$ & $\begin{array}{l}\text { up to } 2 \text { tax credit per child } \\
\text { (additional amounts in some } \\
\text { regions) }\end{array}$ & 46 & 30.8 & 177 & yes & 46 & 6.4 & 177 & no & earning $<55$ are tax-exempt & $\begin{array}{l}\text { "spike" in METR once above } \\
\text { exemption limit; phase-out of main tax } \\
\text { credit adds } 5 \text { pct. points to METR }\end{array}$ \\
\hline Sweden & $4 / 92$ & $\begin{array}{l}30^{4} \\
55^{4}\end{array}$ & - & individual & - & 3 & 6.95 & 121 & yes & \begin{tabular}{|l}
0.4 \\
0.4
\end{tabular} & 33 & - & no & & \\
\hline United Kindgom & $29 / 220$ & $\begin{array}{l}20 / 40 \\
3 \text { rates }\end{array}$ & - & individual & $\begin{array}{c}2 \text { tax credit for married } \\
\text { couples; } 13 \text { tax deduction } \\
\text { for lone parents }\end{array}$ & 23 & 8.4 to 10 & 177 & no & \begin{tabular}{|c|}
$23^{10}$ \\
40 \\
56 \\
76 \\
\end{tabular} & $\begin{array}{r}3 \\
5 \\
7 \\
10 \\
\end{array}$ & - & no & & \\
\hline
\end{tabular}


Abbreviations: SSC = social security contribution; $\mathrm{METR}=$ marginal effective tax rate; PTR = participation tax rate; tfa $=$ tax free allowance; $\mathrm{MW}=$ statutory minimum wage .

Explanatory Notes: Reference year is 1998. Except where noted, all information is for private-sector employees with no other income and not claiming itemised expenses. Income taxes

include local and regional taxes where applicable. Multiple lines of SSC entries are show where payment schedules differ for the different programs (e.g.

unemployment, etc.). Further information, and data for later years, can be found in the EUROMOD country reports (www.iser essex.ac.uk/msule

OECD Tax Database (www.oecd.org/ctp/taxdatabase) and the OECD series Benefits and Wages (www.oecd.org/els/social/workincentives).

1. in $\%$ of median gross earnings of primary earners (not including employer social security contributions)

2. after adding any standard tax free allowances, deductions or exemptions available to single employees

3. insurance is voluntary

4. averages: rates differ between municipalities and/or employers

5. including "Solidarity Surplus Tax" for German unification. MTR increases linearly in-between lower and middle; and middle and top tax band limits.

6. West Germany

7. including regional income taxes where applicable

8. including pension contributions (same tax base as income tax)

9. effective rate taking into account the allowance of $70 \%$ of the tax base for low incomes

10. all earnings are subject to the applicable rate once they exceed these threshold levels 
Table A2. Summary of social benefits available to persons of working-age

\begin{tabular}{|c|c|c|c|c|c|c|c|c|c|c|}
\hline \multirow{3}{*}{ Austria } & \multicolumn{4}{|c|}{ Social Assistance } & \multicolumn{2}{|c|}{ Housing Benefit ${ }^{2}$} & \multicolumn{2}{|c|}{ Family Benefifits ${ }^{3}$} & \multicolumn{2}{|l|}{ Employment-conditional Benefits } \\
\hline & max. amount ${ }^{2}$ & disregard $^{1}$ & $\begin{array}{c}\text { withdrawal } \\
\text { rate }\end{array}$ & taxable & max. amount ${ }^{2}$ & withdrawal rate & amount $^{2}$ & withdrawal rate & workfincome conditions & withdrawal rate \\
\hline & 52 & - & $100 \%$ & $\begin{array}{l}\text { IT: no } \\
\text { SSC: no }\end{array}$ & - & - & $5-7$ per child & $\begin{array}{c}\text { none } \\
\text { (universal payment) }\end{array}$ & 政 & \\
\hline Belgium & 53 & $\begin{array}{l}10 \text { for each } \\
\text { working adult }\end{array}$ & $100 \%$ & $\begin{array}{l}\text { IT: no } \\
\text { SSC: no }\end{array}$ & - & - & $4-13$ per child & $\begin{array}{c}\text { none } \\
\text { (universal payment) }\end{array}$ & - & - \\
\hline Denmark & $\begin{array}{l}90 \\
\text { + housing } \\
\text { allowance }\end{array}$ & $\begin{array}{l}9 \text { for each } \\
\text { working adult }\end{array}$ & $100 \%$ & $\begin{array}{l}\text { TT: : eses } \\
\text { SSC: no }\end{array}$ & 11 & $75 \%$ & $\begin{array}{l}\text { 3.4 per child; ingher for } \\
\text { lone parents }\end{array}$ & $\begin{array}{l}\text { (universal payment) } \\
\text { (u) }\end{array}$ & - & \\
\hline Finland & $\begin{array}{c}58 \\
\text { +reasonable } \\
\text { housing cost }\end{array}$ & & $100 \%$ & $\begin{array}{l}\text { II: no } \\
\text { ssC: no }\end{array}$ & 34 & $80 \%$ & $\begin{array}{l}\text { 5-9 per child; plus } 2 \text { per } \\
\text { child for lone parents; plus } \\
\text { day-care subsidy }\end{array}$ & $\begin{array}{c}\text { none } \\
\text { (universal payment) }\end{array}$ & - & \\
\hline France & 49 & - & $100 \%$ & $\begin{array}{l}\text { IT: no } \\
\text { ssc: no }\end{array}$ & 20 & $34 \%$ & $\begin{array}{l}\text { main benefit: } 7 \text { to } 12 \text { for } \\
\text { second \& further chilren; } \\
\text { special benentits for young } \\
\text { childidren }\end{array}$ & $\begin{array}{l}\text { main benefit: } 100 \% \text { once } \\
\text { income }>174-261\end{array}$ & & \\
\hline Germany & $\begin{array}{l}47^{4} \\
+ \text { reasonable } \\
\text { housing costs }\end{array}$ & $\begin{array}{l}4 \text { for each } \\
\text { working } \\
\text { family } \\
\text { member }\end{array}$ & $75-100 \%$ & $\begin{array}{l}\text { Tinno } \\
\text { ssc: no }\end{array}$ & $\begin{array}{l}45 \\
\text { (if not reciving } \\
\text { social assitsance) }\end{array}$ & $40 \%$ & 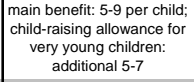 & 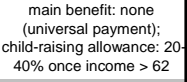 & - & - \\
\hline Greece & . & . & - & $\cdot$ & none at the $n$ & ational level & $\begin{array}{l}\text { 0.5-1 per child plus } \\
\text { additions for large families }\end{array}$ & $\begin{array}{l}\text { reduced in steps for } \\
\text { incomes }>65\end{array}$ & - & \\
\hline Ireland & 56 & $\begin{array}{l}19 \\
\text { (only for 2nd } \\
\text { earner) }\end{array}$ & $100 \%$ & $\begin{array}{l}\text { Tinno } \\
\text { ssc: no }\end{array}$ & 53 & $100 \%$ & 3-4 per child & $\begin{array}{l}\text { (universal payment) } \\
\text { (a) }\end{array}$ & \begin{tabular}{|l}
$60 \%$ of family gross earnings \\
exceeding 88 (higher linint jor jointly working at \\
larger fantilies) 20 hours per week
\end{tabular} & $\begin{array}{c}60 \% \text { (of gross family } \\
\text { earnings) }\end{array}$ \\
\hline Italy & - & - & & & none at the $n$ & ational level & see employment-c & onditional benefits & 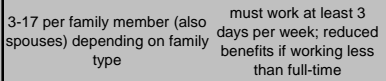 & $\begin{array}{l}\text { reduced in steps for } \\
\text { family incomes > } 73\end{array}$ \\
\hline Luxembourg & 64 & 13 & $100 \%$ & $\begin{array}{l}\text { IT: yes } \\
\text { ssc: reduced }\end{array}$ & $\begin{array}{c}6 \\
\begin{array}{c}\text { (must receive social } \\
\text { assistance) }\end{array}\end{array}$ & $100 \%$ & $\begin{array}{l}\text { 8-13 per child; plus } \\
\text { education allowance for } \\
\text { children aged 3- }\end{array}$ & $\begin{array}{l}\text { (universal payment) } \\
\text { nant }\end{array}$ & $\cdot$ & - \\
\hline Netherlands & 49 & - & $100 \%$ & $\begin{array}{l}\text { yes, but max. } \\
\text { amountis } \\
\text { shown on net } \\
\text { basis }\end{array}$ & 6 & $54 \%$ & 2.7 per child & $\begin{array}{l}\text { none } \\
\text { (universal payment) }\end{array}$ & & \\
\hline Portugal & 59 & & $100 \%$ & $\begin{array}{l}\text { IT: no } \\
\text { SSC: no }\end{array}$ & none at the $n$ & ational level & 4 per child & $\begin{array}{l}\text { reduced to } 3 \text { per child } \\
\text { once income }>71\end{array}$ & - & - \\
\hline Spain & & none at the nati & tional level & & none at the $n$ & ational level & $\begin{array}{l}2 \text { for first child, } 0.2 \text { for } \\
\text { further children }\end{array}$ & $100 \%$ once income $>55$ & - & \\
\hline Sweden & $\begin{array}{l}35 \\
\text { +reasonable } \\
\text { housing cost }\end{array}$ & & $100 \%$ & $\begin{array}{l}\text { II: no } \\
\text { ssc: no }\end{array}$ & 17 & $\begin{array}{l}33 \% \% \\
\text { (disregard of } 18)\end{array}$ & $4-8$ per child & $\begin{array}{l}\text { (universal payment) } \\
\text { nat per }\end{array}$ & - & - \\
\hline United Kindgom & 51 & $2-4$ & $100 \%$ & $\begin{array}{l}\text { II: no } \\
\text { SSC: no }\end{array}$ & $\begin{array}{l}100 \% \text { of recognised } 6 \\
\text { rent; } 1000 \text { of } \\
\text { council tax }\end{array}$ & $\begin{array}{l}5 \% \text { (housing benefit); } \\
20 \% \text { c council tax } \\
\text { benefitit }\end{array}$ & 3-5 per child & $\begin{array}{l}\text { none } \\
\text { (universal payment) }\end{array}$ & 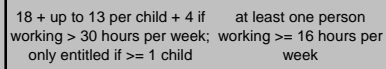 & $\begin{array}{l}70 \% \text { of family } \\
\text { income }>29\end{array}$ \\
\hline
\end{tabular}


Abbreviations: IT = income tax; SSC = social security contributions

Explanatory Notes: Reference year is 1998. Rules for social benefits can vary between regions or municipalities. Where social assistance is subject to job-search or other conditions (e.g. in Denmark), it is assumed that both spouses comply with the relevant requirements. All information is for families with two children. IT = income tax; SSC = social security contributions. Further information, and data for later years, can be found in the EUROMOD country reports (www.iser.essex.ac.uk/msu/emod/documentation/countries/), the OECD Tax Database (www.oecd.org/ctp/taxdatabase) and the OECD series Benefits and Wages (www.oecd.org/els/social/workincentives)

2. cash assistance for privately rented accommodation. Housing benefits may be paid through the social assistance program. In this case, they are already reflected in the social

assistance amounts shown in this table.

3. in addition to family-related tax concessions shown in the companion table under income tax. Does not include any benefits available for pregnancy, childbirth, parental leave, or childcare benefits.

4. West Germany. 
Table A3. Average marginal tax rates

\begin{tabular}{|c|c|c|c|}
\hline Country & Primary earners & Secondary earners & PE tax / SE tax \\
\hline Austria & 0.54 & 0.44 & 1.24 \\
\hline Belgium & 0.58 & 0.60 & 0.98 \\
\hline Denmark & 0.56 & 0.54 & 1.04 \\
\hline Finland & 0.61 & 0.47 & 1.32 \\
\hline France & 0.54 & 0.53 & 1.01 \\
\hline Germany & 0.54 & 0.59 & 0.92 \\
\hline Greece & 0.30 & 0.28 & 1.07 \\
\hline Ireland & 0.35 & 0.43 & 0.82 \\
\hline Italy & 0.53 & 0.48 & 1.10 \\
\hline Luxembourg & 0.39 & 0.44 & 0.89 \\
\hline Netherlands & 0.50 & 0.47 & 1.08 \\
\hline Portugal & 0.38 & 0.42 & 0.89 \\
\hline Spain & 0.33 & 0.32 & 1.02 \\
\hline Sweden & 0.63 & 0.54 & 1.15 \\
\hline United Kingdom & 0.44 & 0.31 & 1.43 \\
\hline
\end{tabular}

Note: Average effective marginal tax rates for primary earners in one-earner couples and secondary earners conditional on working Source: EUROMOD Microsimulation Model.

Table A4. Annual marriage penalties in 2007 euros for families with no children, 1998

\begin{tabular}{|c|c|c|c|c|c|c|c|c|c|c|c|c|c|c|c|}
\hline Family Income Percentiles & AT & BE & DK & FI & FR & GE & GR & IR & IT & LU & NL & PT & SP & sw & UK \\
\hline PE 0 - SE 0 & 4905 & 5217 & -2990 & 2066 & 5907 & 760 & 0 & 2224 & 0 & 8110 & 2443 & 0 & 0 & 10384 & 2418 \\
\hline PEp10 - SE 0 & 7510 & 5319 & 4966 & 7263 & 7306 & 4008 & -24 & 7069 & -1527 & 13281 & 6312 & 1652 & -421 & 14126 & 4994 \\
\hline PEp10 - SEp10 & 4875 & 5684 & 199 & 2214 & 2440 & 2587 & -24 & 4471 & -437 & 8298 & 5385 & 94 & 0 & 2251 & 3336 \\
\hline PEp50 - SE 0 & 7780 & 5861 & 8184 & 8340 & 6915 & 3273 & -145 & 5078 & -957 & 9089 & 6190 & 1241 & -969 & 14508 & 8075 \\
\hline PEp50 - SEp10 & 5228 & 6741 & 264 & 2224 & 1485 & 1913 & -145 & 1235 & -456 & 3201 & 4886 & -317 & -127 & 2251 & 3587 \\
\hline PEp50 - SE p50 & 0 & 1655 & 0 & 0 & -170 & -149 & 11 & -1507 & -625 & -3827 & 961 & 142 & 0 & 0 & -609 \\
\hline PEp90 - SE 0 & 8020 & 6027 & 8985 & 9621 & 1092 & -356 & 0 & 5922 & -1619 & 3121 & 8937 & -999 & -2122 & 14508 & 13411 \\
\hline PEp90 - SEp10 & 5969 & 6779 & 1031 & 3223 & -3263 & -1468 & 0 & 2698 & -1207 & -3539 & 7560 & -2434 & -320 & 2251 & 9049 \\
\hline PEp90 - SEp50 & 0 & 1954 & 1464 & 0 & -3262 & -5517 & 106 & -1212 & -1377 & -7801 & 0 & -1169 & 0 & 0 & 3148 \\
\hline PEp90 - SEp90 & 0 & 3077 & 0 & 0 & -1251 & -1682 & 287 & 0 & -1677 & -3662 & 0 & 638 & 0 & 0 & -610 \\
\hline
\end{tabular}

Note: The table shows marriage penalties on an annual basis for hypothetical families in 2007 Euros. The calculations are done for different earnings levels for the primary and secondary earner and the earnings levels refer to percentiles in the earnings distribution for primary and secondary earners, respectively. The marriage penalty is calculated as the change in a couple's combined (net-)tax liability upon separation. It is assumed that all individuals occupy rental housing. Following separation, each spouse is assumed to bear rental costs amounting to $50 \%$ of the costs in the married scenario. Further, each spouse retains custody of one child. 1998 figures are converted to 2007 euros using national indices of compensation per employee. Exchange rates are, respectively, the irrevocable euro exchange rates (12 euro countries) and 2007 average annual exchange rates (non-euro countries: Denmark, Sweden, UK).

Sources: EUROMOD microsimulation model, OECD Economic Outlook 82, and Danmarks Nationalbank. 


\section{Figure A1. Marginal tax rates of secondary earners for couples with two children}

In percent, at selected earnings levels as a function of primary earnings (vingtiles)
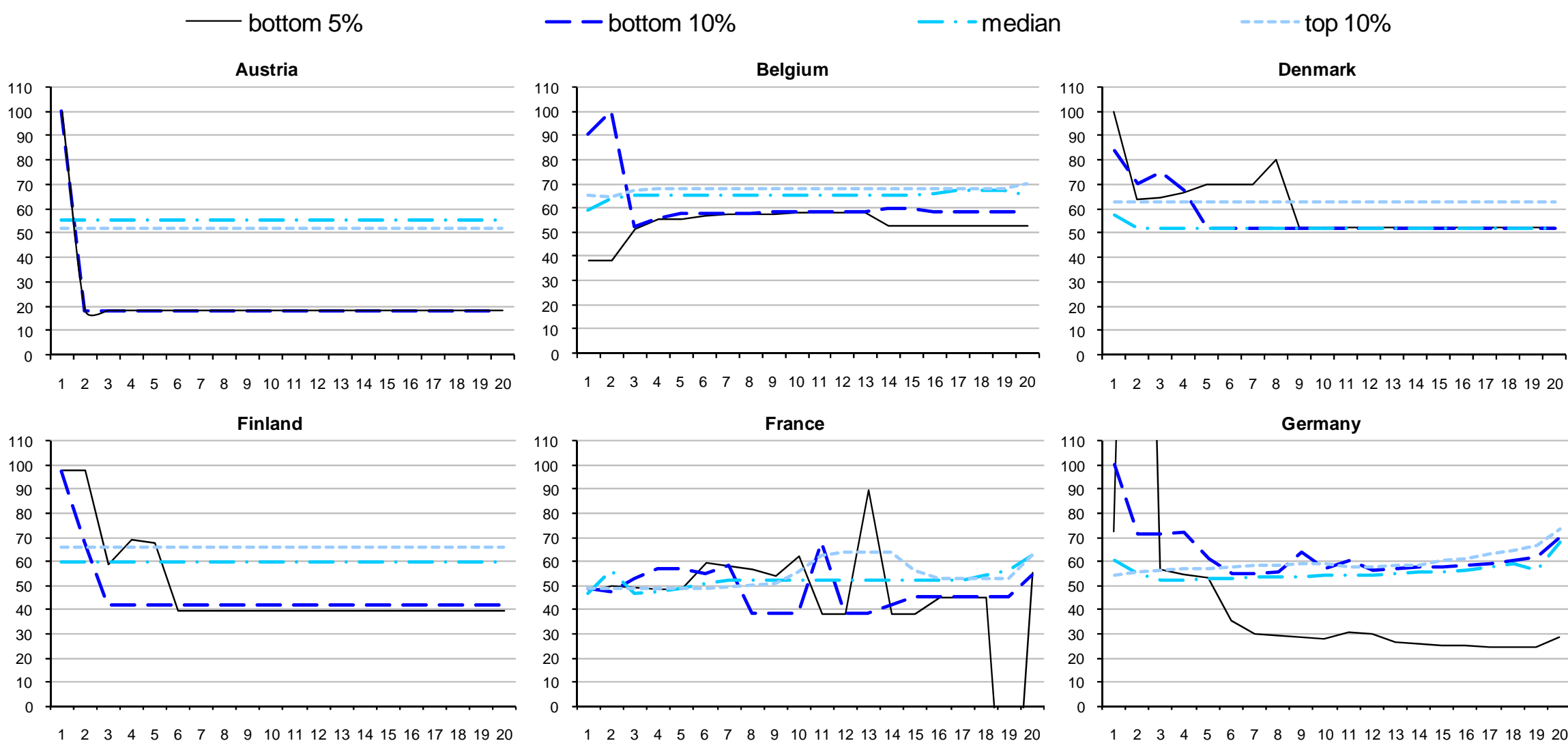

$\begin{array}{lllllllllll}1 & 2 & 3 & 4 & 5 & 6 & 7 & 8 & 9 & 1011 & 121314151617181920\end{array}$

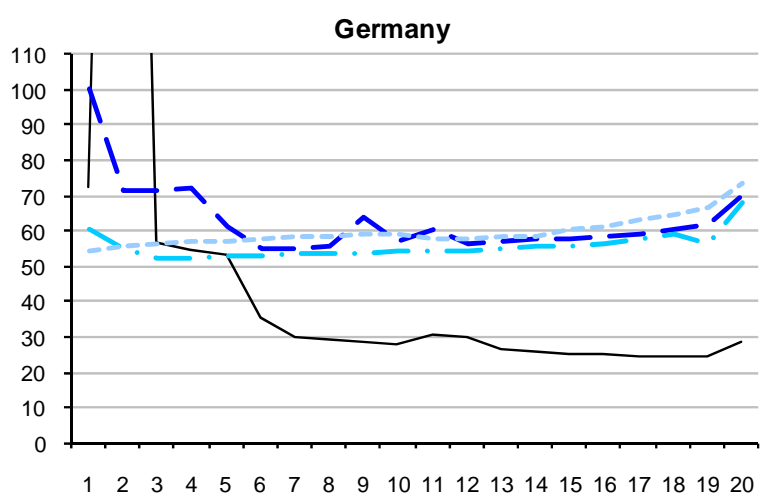

Figure continues on next page 
Figure A1. (cont.)
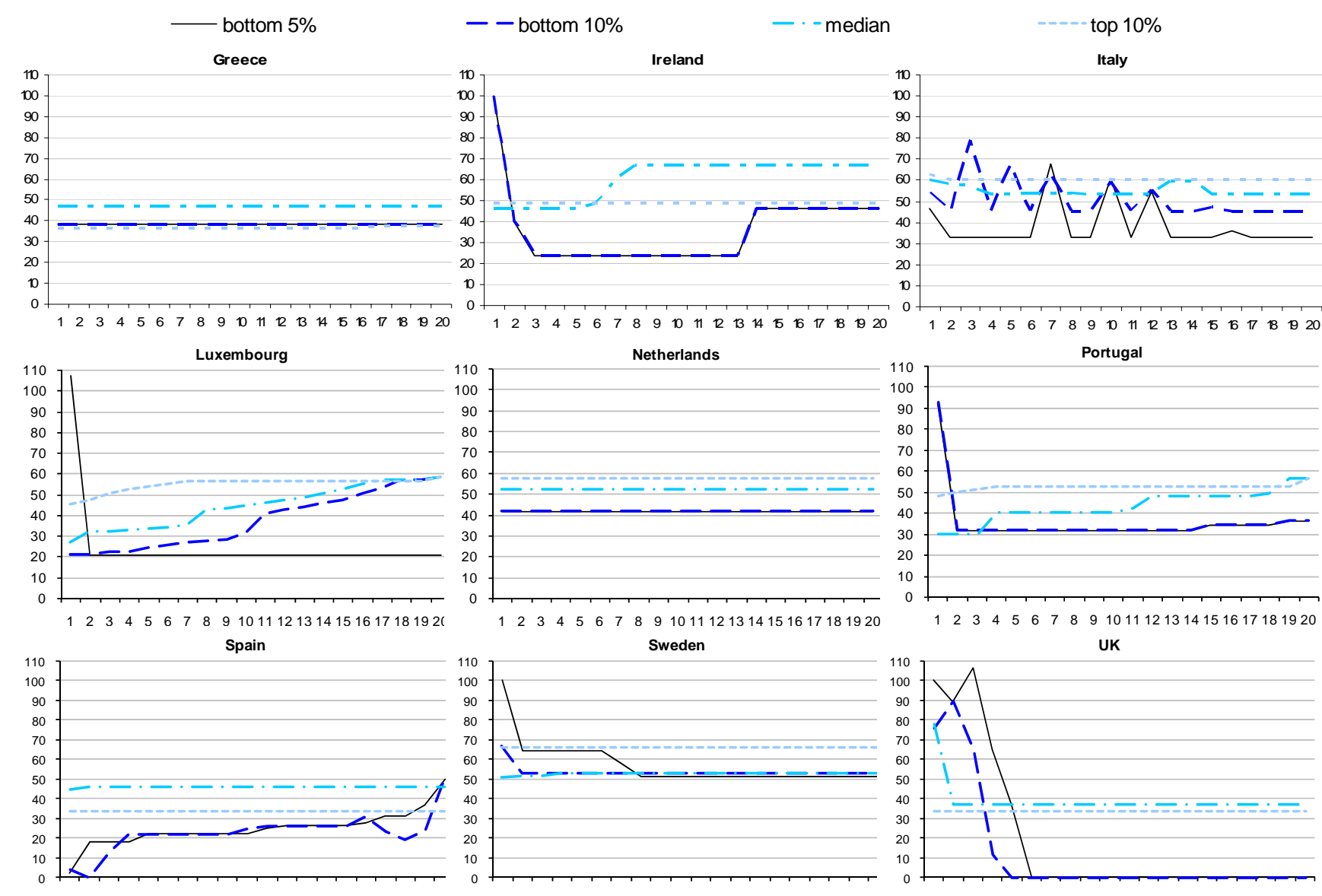

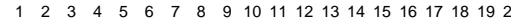

$12304556 \quad 7 \quad 8 \quad 9101112131415161718192$

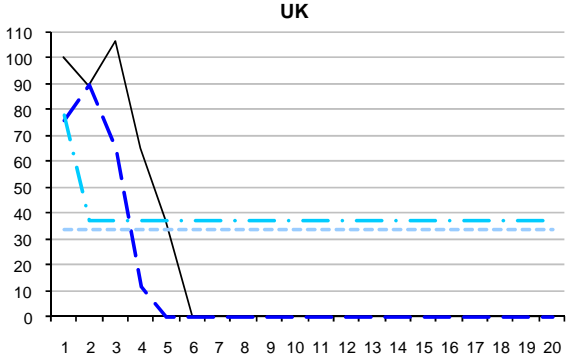

Note: Each figure shows the marginal tax rate of the secondary earner (SE) in percent as a function of the earnings of the primary earner (PE), depicted by vingtile group in the PE earnings distribution. The graphs are shown for four different SE earnings levels: the lowest vingtile (SEp5), the lowest decile (SEp10), the median(SEp50), and the top decile (SEp90) of the SE earnings distribution. Source: EUROMOD microsimulation model. 


\section{Figure A2. Participation tax rates of secondary earners for couples without children}

In percent, at selected earnings levels as a function of primary earnings (vingtiles)

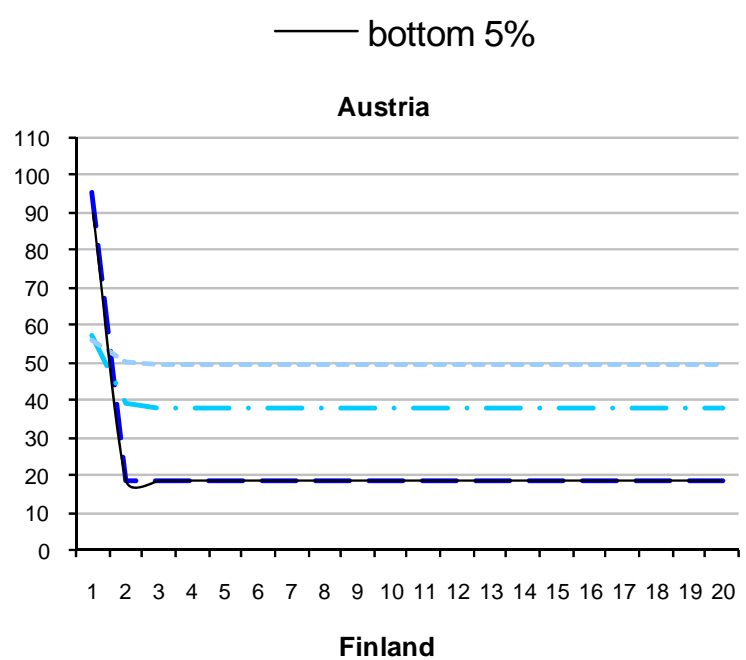

— - bottom 10\%

- - median

top $10 \%$
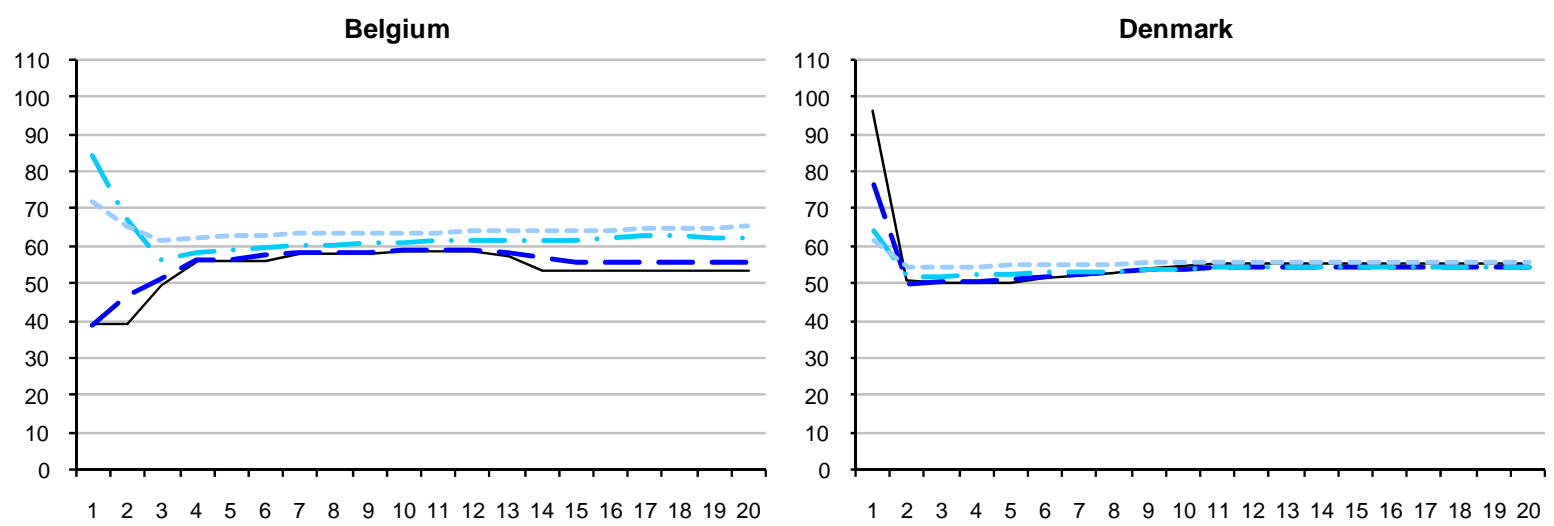

France

Germany
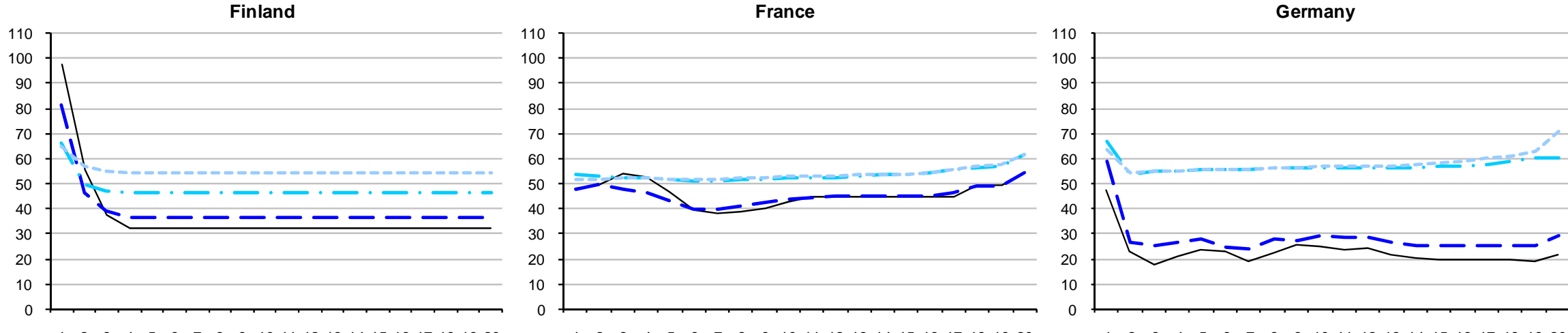

$1 \quad 2 \quad 3 \quad 4 \quad 556 \quad 7 \quad 8 \quad 91011121314151617181920$

$\begin{array}{llllllllllllll}1 & 2 & 3 & 4 & 5 & 6 & 7 & 8 & 9 & 1011 & 121314 & 151617181920\end{array}$

Figure continues on next page 
Figure A2. (cont.)
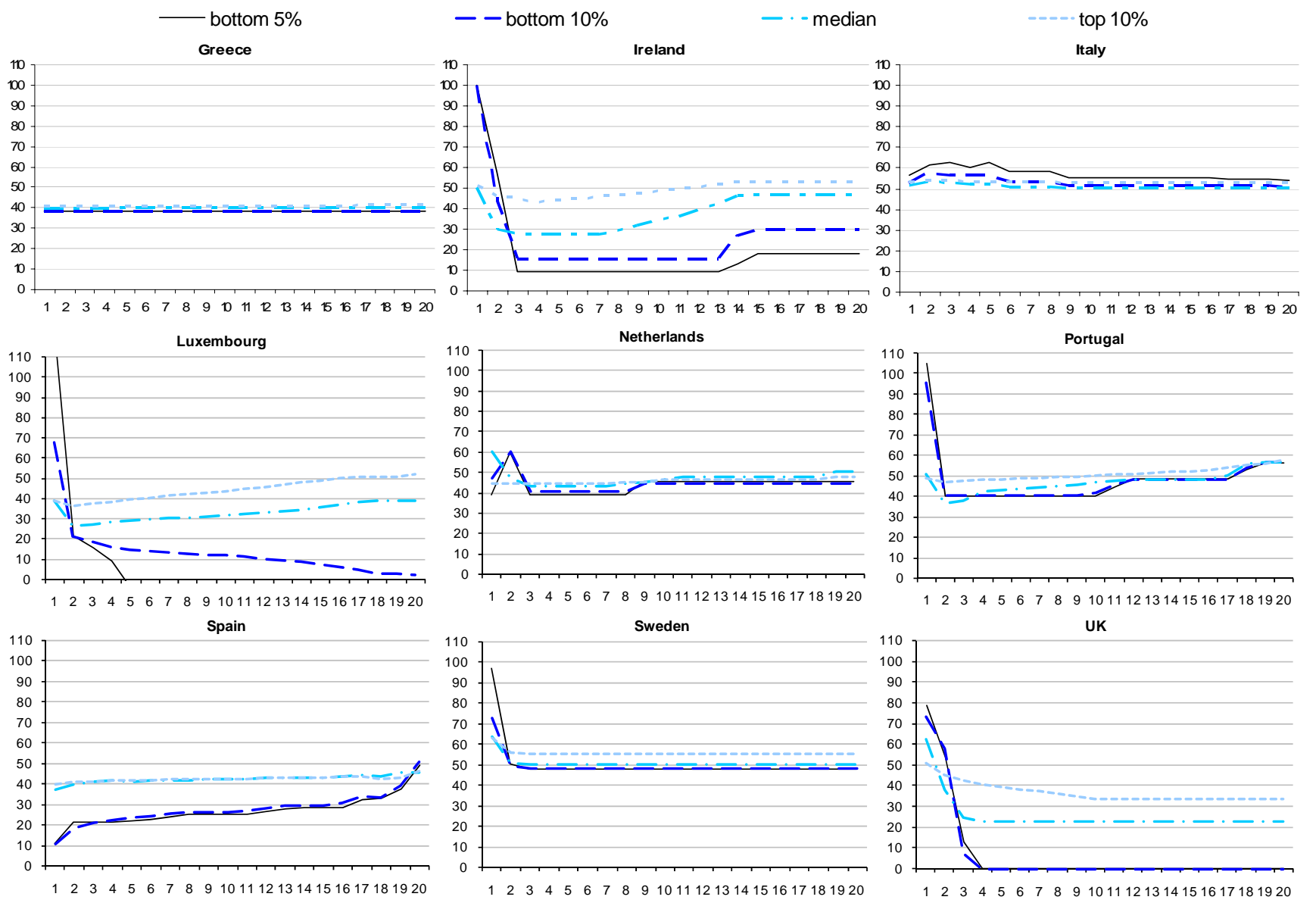

Note: Each figure shows the participation tax rate of the SE in percent as a function of the earnings of the PE, depicted by vingtile group in the PE earnings distribution. The graphs are shown for four different SE earnings levels: the lowest vingtile (SEp5), the lowest decile (SEp10), the median(SEp50), and the top decile (SEp90) of the SE earnings distribution. Source: EUROMOD microsimulation model. 